Federal Reserve Bank of Dallas

Globalization and Monetary Policy Institute

Working Paper No. 230

http://www.dallasfed.org/assets/documents/institute/wpapers/2015/0230.pdf

\title{
Do Bank Loans and Local Amenities Explain Chinese Urban House Prices?*
}

\author{
Daisy J. Huang \\ Hong Kong University of Science and Technology \\ Charles K. Leung \\ City University of Hong Kong \\ Baozhi Qu \\ China Merchants Group
}

March 2015

\begin{abstract}
Based on Chinese city-level data from 1999 to 2012 and controlling for geological, environmental, and social diversity, this study suggests that credit plays a significant role in driving up house prices after the Great Recession, whereas property prices only influence bank lending before 2008. Local amenities such as higher education, green infrastructure, healthcare, and climate also positively affect house prices. Moreover, the impacts of bank loans on housing prices tend to be related to the level of amenities, suggesting an integrated approach (i.e. combining macroeconomic and urban economic variables) of housing market for the future research.
\end{abstract}

JEL codes: G21, O18, R11

\footnotetext{
* Daisy J. Huang, HKUST Jockey Club Institute for Advanced Study, The Hong Kong University of Science and Technology, Clear Water Bay, Kowloon, Hong Kong. huangjur@gmail.com. Charles K. Leung, Department of Economics and Finance, City University of Hong Kong, Tat Chee Avenue, Kowloon Tong, Hong Kong. kycleung@cityu.edu.hk. Baozhi Qu, China Merchants Group, 38th floor, Shun Tak Centre, 168-200 Connaught Rd. C. HK. baozhiqu@cmhk.com. The authors would like to thank Belton Fleisher, Pohan Fong, Xu Han, Vikas Kakkar, Kamhon Kan, Fred Kwan, Jennifer Lai, Huimin Li, Mi Lin, Chung Yi Tse, Yi Wen, Isabel Yan, Zan Yang and the participants at the 2013 ASSA-CEANA Meeting, the Seventh Biennial Conference of the Hong Kong Economic Association, the 2012 AsRES-AREUEA International Conference, the GCREC 2012 Annual Conference, WEA conference (2012), and at the City University Brown Bag seminar, and especially anonymous referees for their comments. In addition, we are grateful to City University of Hong Kong for its financial support. The work described in this paper was partially supported by a grant from the Research Grants Council of the Hong Kong Special Administrative Region, China [Project No. CityU 144709]. The hospitality of the ISER, Osaka University is also gratefully acknowledged. The views in this paper are those of the authors and do not necessarily reflect the views of the China Merchants Group, the Federal Reserve Bank of Dallas or the Federal Reserve System.
} 


\section{Do bank loans and local amenities explain Chinese urban house prices?}

\section{Introduction}

This paper studies the housing market of China and is built on several strands of the literature. First, this paper is related to the debate on whether credit aggregates cause the property market boom, or the other way round. Although the relationship between credit aggregates and house prices is significantly positive and economically strong in many countries, the direction of causality and the propagation mechanism remain to be resolved empirically. For instance, some studies of the 2006 U.S. real estate market collapse suggest that the subprime mortgage expansion was responsible for bursting the bubble (e.g., Mian and Sufi 2009; Pavlov and Wachter 2004, 2006). However, other authors argue that no conclusion concerning causality should be drawn (e.g., Wheaton and Nechayev, 2008; Davis and Zhu, 2011). Similarly, Collyns and Senhadji (2002) find evidence for a channel from credit to property price appreciation during the 1997 Asian Financial Crisis. Yet, Gerlach and Peng (2005) claim that property prices in Hong Kong during that period were weakly exogenous, and the causality went from property prices to bank loans, rather than the other way around.

The China's housing market, which has received significant domestic and international attention recently, faces the same set of questions as other markets. According to the data from the CEIC and the National Bureau of Statistics of China (NBSC), the GDP has grown by a phenomenal rate of $479 \%$ between 1999 and 2012, house prices have been up by $200 \%$, but the loan balance has increased tenfold astonishingly. The banking system issued loans worth RMB10 trillion in 2009 alone; this was equivalent to almost one-third of the country's GDP in that year. Together, these figures ${ }^{1}$ raise great concerns in business, policy, and academic circles about the sustainability of China's housing market. It is natural to ask whether these housing

\footnotetext{
${ }^{1}$ These figures are in nominal terms.
} 
loans are created by market demand. Or, the bank loans are simply being injected into the economic system by policy decisions? Will China experience a housing market collapse followed by decades of recession, as happened in Japan? Many researchers have focused on the housing markets at the national or provincial levels. ${ }^{2}$ Although these aggregate-level studies obviously have merits, research at a more disaggregated level would clearly be complementary. For instance, different cities or different regions within the same country may display different patterns, or have different trends in the macroeconomic variables. City-level data not only provide us with a larger sample size, but also are less vulnerable to aggregation bias (Hanushek et al. 1996). Furthermore, the structure of panel data enables us to gain insights on the debate from both the cross-sectional and the temporal dimensions.

Since this study focuses on city-level data, it naturally connects to the second literature, which relates the house price to the local amenities. As housing is a durable and immobile consumption good, location and local amenities matter. Other things being equal, people prefer housing in locations that offer a higher quality of life. Rosen (1979) and Roback (1982) have established that average wages and real estate prices in different places adjust to reflect the values of spatially tied features. Following Rosen and Roback's pioneer work, there have been many studies testing and confirming the existence of compensating differentials in wages and residential property prices in both developed and developing economies (e.g., Blomquist et al. 1988; Gyourko and Tracy 1991; Shapiro 2006; Berger et al. 2008). China is large enough to include places characterized by very different climates, environments, and types of social development. The compensating differentials literature contains enlightening research on China, including studies by Zheng and Kahn (2008), Zheng, Fu, and Liu (2009), Zheng, Kahn, and Liu (2010), and Zheng, Cao, and Kahn (2011). Our paper complements previous research by including a broader set of amenities and with a focus of their impacts on housing prices.

Although bank loans and local amenities are seemingly unrelated, we combine analysis of both factors in one research for simple economic reasons. First, it is more than likely that both the credit availability and the geographical distribution of urban amenities have impacts on the city-level demand. And as a matter of fact, loans and some amenity measures may be interacted. While some amenities such as climate may be less influenced by human activities, other

\footnotetext{
${ }^{2}$ For instance, see Wang and Wen (2012) and the reference therein.
} 
amenities such as public health service, or "local fiscal climate" by Gyourko and Tracy (1991), clearly depend on economic activities. Not surprisingly, the second type of amenities and loans can be both tied to the level of economic development, and hence creates some relationships among them. While some previous literature emphasizes how the differences in amenities explain the cross-sectional variations in housing prices, some other literature focuses on how the cyclical movements in bank loans lead to house price fluctuations. Yet in the context of a panel of city-level house prices, as both cross-sectional and temporal components are present, it is not clear a priori which factor will dominate. Integrating these two factors in a simple yet unifying framework should provide a more complete picture of the housing markets.

To achieve the stated objective, it is necessary to select a diverse sample that is also representative of China. Our dataset includes 29 cities; most are provincial capitals that are scattered across the whole country. In addition, most are among the largest cities in their regions, and have a relatively large number of housing transactions. The house price figures are therefore more representative and less likely to suffer from a small sample bias. However, an analysis using simple regression, even with all of the relevant variables included, would still deliver biased estimates, partly due to the multicollinearity among the amenity measures, and partly because the effect of amenities on house prices is also indirectly reflected in income. For instance, both number of doctors and number of hospital beds shared by every 10,000 local population are indicators of healthcare condition; these two measures have a correlation coefficient of 0.78 . We tackle the multicollinearity problem by the principal component analysis technique (PCA hereafter). The idea is to reduce various measures to a few variables, and at the same time retain most of the variance in data. In this analysis, 17 amenity measures are consolidated into five categories: climate, air pollution, crime rate, health care, and social development. The formal recognition of the local-amenities differences has important implications for the empirical strategies. For instance, in a city with "better" amenities, these amenities would affect the house prices directly (as people are willing to pay for them), and also affect the house prices indirectly, as an improvement of local amenities may enable the same group of employees to generate more output, as well as attract more capable people to that city and eventually raise the aggregate income of the city. ${ }^{3}$ Additionally, it seems reasonable to

\footnotetext{
${ }^{3}$ Among others, see Davis et al. (2014), Wang and Xie (2011) for more discussion on this.
} 
conjecture that with growing income, households would be more willing to pay for certain amenities. ${ }^{4}$ It follows that a two-step procedure is necessary to disentangle the direct and the indirect effects. We first regress income on the principal components of the amenities, and retain the residuals. We label these residuals as filtered income, as they are the part of the income not predicted by local amenities. Then the filtered income is added to the property price regression, together with the normalized loan, the amenities, and the other variables. The natural logarithms of real house prices and real incomes, as well as the normalized loan are further detrended to obtain reliable estimation results. And in order to adjust the within city correlation, clustered standard errors are employed for statistical inference.

Our empirical findings suggest that credit plays a significant role in driving up house prices after the Great Recession, whereas the reversed effect of property prices on bank lending is only present before 2008. More specifically, before the 2008 financial crisis, we find loan volume does not have any significant impact on home prices. However in the post-recession era, such impact is positive and significant at the 5\% significance level. If the normalized loan expands by $1 \%$, then the real home prices would be higher by 16.1 basis points next year. In terms of standardized coefficient, an increase of one standard deviation in loan GDP ratio would predict a following 0.179 standard deviations' expansion in real housing prices in the next year. On the other hand, property prices significantly influence bank credit before 2008, but not after. In case of $1 \%$ appreciation of real home prices, the bank lending would be greater by 49.3 basis points. In other words, a rise of one standard deviation in house prices would lead to an increase of 0.371 standard deviations in loans in the following year.

Our empirical results also confirm that location is economically very significant. Not surprisingly, people are willing to pay more for housing units located in cities with rich resources in higher education and great green infrastructure. People prefer to live in big cities because of the better economic opportunities, in spite of the crowding and higher crime rates. If the social development component combining higher education, green coverage, and population density has a score greater by one standard deviation, the property prices would be 0.401 standard deviations higher. The amenity indicators capture the location heterogeneity so well that the regional dummies are no longer significant. In an alternative specification, amenity variables

\footnotetext{
${ }^{4}$ In other words, the income elasticity of some amenities could be higher than unity.
} 
such as climate, health care, and social development are found to be significantly and negatively interacted with the normalized loan. It suggests home prices in cities with more desirable amenities are less sensitive to credit expansion.

The organization of this paper is simple. The next section provides some background on the housing markets, bank loans, and local amenities in China. The literature review is followed by a discussion of the data, and then by a description of the methodology. The results are then presented, and the conclusions are given in the last section.

\section{Background on the Housing Markets, Bank Loans, and Local Amenities}

For many households throughout the world, a house is not only a shelter, but also the most important investment the household has. Yet for the older generation in mainland China, there was no such thing as private property. Most people lived in apartments assigned by their employers. These arrangements continued until the 1980s when the government launched its housing reform. The administrative housing allocation system was officially abolished in 1998. Since then the government has introduced a series of macro land-use policies to encourage the development of the new private housing market. ${ }^{5}$ Under the joint forces of the private market and government stimulation policies, real estate prices began to increase in $2001^{6}$, and then accelerated until 2007. In Figure 1, we use floor space completed as a proxy for new supply in the real estate market. Floor space sold is intended to stand for demand. When the floor space completed is greater than that sold, the amount of housing unit inventory increases and property prices are kept low. When the new supply does not meet the demand, the amount of inventory in the housing market decreases and the price rises ${ }^{7}$. At the more disaggregated level, 21 out of the

\footnotetext{
${ }^{5}$ For a detailed discussion of these policies, please refer to Leung and Wang (2007), and Zhao et al. (2008).

${ }^{6}$ Coastal cities like Hangzhou, Shanghai, and Shenzhen first experienced the rise of housing prices in around 2001 or 2002. Prices in interior cities started to appreciate a little bit later (in around 2003 or 2004).

${ }^{7}$ Due to the existence of pre-sale of housing units, the comparison between housing completion and housing transaction is probably an imperfect supply-demand indicator. On the other hand, different real estate developments may have different pre-sale periods and to our knowledge, there is no official data which corrects this "pre-sale gap". In addition, pre-sale means that the ownership of the unit is shifted from the developers to the buyers before the unit is completed. In other words, the existing stock at the time of pre-sale does not increase. The buyers still need to buy or rent other housing units as shelters. It only provides a "hedge" of the house price fluctuations. And there are instances that developers actually go bankrupt after pre-sale and hence are unable to deliver promised units. Being aware of all these limitations, we proceed with this comparison as a proxy.
} 
29 major cities in China had an average housing price growth rate of over $10 \%$ annually from 1999 to 2012. An average-sized 120-square-meter apartment in Beijing cost 36 years of disposable income for an average resident in 2004, and by 2012 it cost 52 years of disposable income. Furthermore, as the China Real Estate Index System reported, in 2010 alone the house prices in Beijing surged by $37.1 \%$, and by $47.1 \%$ in Hangzhou. ${ }^{8}$

As property prices boomed, so did real estate investments. From 1986 to 2012, nominal investment in China grew at an annual rate of $18 \%$. In contrast, nominal real estate investment expanded at a nearly doubled rate; it grew $32 \%$ per year from RMB10 billion to 7,180 billion. The proportion of real estate investment over total investment soared from $2.6 \%$ in 1986 to $28 \%$ in 2012. As investments made up 47.8\% of China's GDP, real estate investment accounted for $14 \%$ of the total economic activity. Figure 2 provides a visualization of these observations.

\section{[Insert Figure 1, Figure 2 about here.]}

In addition to the frenzied house prices and real estate investments, we also provide a brief review of the monetary policy after 1978. The broad money and outstanding loans increased at an average annual rate of $23 \%$ and $19 \%$ respectively. Both were faster than the nominal GDP growth which was on average 16\%. From Figure 3, we can see that the proportion of loans issued over GDP has increased to $123 \%$ in 2013 from 52\% in 1978. The evolving path of the ratio of M2 to output is even more startling. In the late 1970s, M2 accounted for less than $25 \%$ of gross production, whereas at the end of the sample period, it was almost $190 \%$ of GDP. In 2009 alone, the new loans issued were close to RMB10 trillion, a 33\% expansion over the previous year. In 2010, the credit aggregates increased by another RMB8 trillion. The total loan portfolio was expanded by over 50\% right after the 2008 financial crisis. Together with the RMB4 trillion stimulus package, these loans were supposed to finance infrastructure projects, but many ended up going to giant the state-owned enterprises where they were used to finance the purchase of real estate instead. ${ }^{9}$ According to $\mathrm{Wu}$ et al. (2012), residential land auctions witnessed land prices doubled in eight major cities in 2009, which in their opinion can be attributed to the massively leveraged purchases by the state owned enterprises (SOEs hereafter).

\footnotetext{
${ }^{8}$ Soufun developed the China Real Estate Index System (CREIS) to monitor real estate prices in one hundred cities. For more, please refer to Anonymous (2011 May 11). The property report: China's tougher mortgage policies. Wall Street Journal.

${ }^{9}$ See Davis, B. (2011 Jun 27). China real estate concerns rise. Wall Street Journal.
} 
They also show that on average, state-owned corporations pay $27 \%$ more than other bidders for the same land parcels. In some ways, the current situation in China's housing market resembles the pre-crisis U.S. property market. The overheated real estate market and the rapid credit expansion have drawn a lot of attention, as the affordability of housing is of great concern to the general public, and the bursting of a real estate bubble could cause serious problems for the banking system and the macroeconomy.

[Insert Figure 3 about here.]

China has achieved great economic success since its economic reform and opening up. But it has always been a great country with huge cross-sectional variations in amenities. According to the Encyclopedia Britannica, China is the third largest country by area. It stretches from the Russian border in the north, to the South China Sea. In the west, it extends into the Pamir Mountains, the "Roof of the World". The landscape is vast and diverse and the climatic and geological environments vary from region to region. Thus, it may be interesting to investigate how the local housing markets behave given such geographical diversity. Our sample of 29 large cities, most of them provincial capitals, is highly representative for such diversity. For example, our sample includes Kunming, the "City of Eternal Spring" in the south-western Yunnan province ${ }^{10}$, and the "Ice City" of Harbin, located in the north-eastern Heilongjiang province, which has the coldest and longest winter in China. Temperatures in Kunming range from $31.3^{\circ} \mathrm{C}\left(88.3^{\circ} \mathrm{F}\right)$ in the summer to $-4^{\circ} \mathrm{C}\left(24.8^{\circ} \mathrm{F}\right)$ in the winter, while the lowest recorded temperature in Harbin is $-37.3^{\circ} \mathrm{C}\left(-35.1^{\circ} \mathrm{F}\right)$ in the same period. The geology not only shapes the diversified climate, but also affects the "colors" seen in satellite photos. Western China is covered by deserts, mountains, and plateaus, and has an arid climate. In contrast, the east, consisting of the Northeast Plain, the North China Plain and the Middle-Lower Yangtze Plain, is characterized by humid warm weather. Correspondingly, the green coverage ratio is higher in the east than in the west. The average urban green coverage ratio is over $36 \%$ in eastern cities in our sample, whereas this figure is only $29 \%$ in the western cities.

\footnotetext{
${ }^{10}$ There is a special article in the December 8, 2012 issue of iMoney magazine called "New favorite mainland city of Hong Kong capital, Kunming" (in Chinese). It gives a very detailed description of Kunming's climate and geography, and how these features are going to attract Hong Kong capital. In that article, Kunming is compared to the warm and beautiful Florida.
} 
These broad climatic and geological environments are reflected in large cross-sectional variations in the cities. The availability of higher education also varies dramatically across regions. In 1995, the central government launched an initiative called "Project 211" to promote China's higher education by providing funding to universities. So far, only 112 of the 2,358 universities and colleges in the country are enrolled in the program ${ }^{11}$. Therefore, a designation as a 211 Project institution is an indicator of educational quality. The number of universities sponsored by the Project in a city may be a proxy for cultural richness, higher education quality, or even the human capital environment. The distribution of these universities is uneven across the country, with 26 in Beijing, ten in Shanghai, eight in Nanjing, seven in Wuhan, and seven in Xi'an. In total, these five cities are home to half of the best universities and colleges in the nation; there is only one such institution in most other major cities, and none in Ningbo and Shijiazhuang.

The same pattern can be seen in the distributions of the health workforce and facilities. There are 3.6 and 3.4 doctors per 1,000 people in Guangzhou and Beijing respectively, which is comparable to the standards in European countries such as Germany, France, and Denmark. ${ }^{12}$ In contrast, the doctors density in Chongqing and Shijiazhuang is only 1.4 and 1.8, respectively. The density of hospital sickbeds is also high in Beijing and Guangzhou and low in Chongqing and Shijiazhuang. In Guangzhou, there are 5.7 sickbeds serving every 1,000 people. The figure is 4.8 in Beijing. But 1,000 people have to share 2.4 sickbeds in Chongqing, and 3 in Shijiazhuang.

Air pollution also varies significantly across cities. The World Health Organization (WHO hereafter) issued in 2011 a database ${ }^{13}$ recording outdoor air pollution in 91 countries and 1,100 cities. According to this database, 20 among the top 100 most polluted cities are in China. In particular, Beijing ranked the fifth within the country and fiftieth world-wide. In fact, according to the state-run Xinhua news agency and the air quality daily report ${ }^{14}$ by the Beijing Municipal Environmental Protection Bureau, Beijing's air pollution hit dangerous levels on ten

\footnotetext{
${ }^{11}$ There are more and more colleges and universities in China nowadays, but the 211 Project probably will not expand any more.

${ }^{12}$ The worldwide data are available on the WHO website http://www.who.int/gho/health_workforce/physicians_density/en/index.html.

${ }^{13}$ The full dataset can be downloaded from http://www.who.int/phe/health topics/outdoorair/databases/en/.

${ }^{14}$ The data are available on this webpage: http://www.bjepb.gov.cn/air2008/Air.aspx?time=2013-1-28. Historical data can be obtained by modifying the enquiry date.
} 
days in January 2013, and on one day, the $\mathrm{PM}_{2.5}{ }^{15}$ reading was 993 micrograms per cubic meter. Although air pollution is challenging sustainable growth everywhere in China, the south remains in relatively better condition. In the WHO database, the top five polluted cities, including Lanzhou, Xining, Urumqi, Jinan, and Beijing, are all in the north, and the least polluted five cities $^{16}$, Haikou, Nanning, Fuzhou, Kunming, and Guangzhou, are all in the south. As the Chinese grow rich, so are their marginal valuations on quality of life. The three large-scale local protests $^{17}$ in 2012 against environment-harming industrial projects are convincing evidence of people's willingness to pay for desirable amenities.

\section{Literature Review}

Changes in the real estate and credit markets can be mutually reinforcing. House price appreciation can cause credit expansion. As illustrated by Kiyotaki and Moore (1997) and other authors, as both households and firms use property as collateral for borrowing, the net worth of households' collateralizable assets increases with house prices. Such change in net worth enables them to borrow even more. From the banks' point of view, real estate values affect their capital positions. In good times, the loans secured by real estate collateral are even safer, and the banks' direct holdings of property assets also appreciate. This perception increases financial institutions' risk-taking capacity and their willingness to extend credit, so they pour more loans into the economy. Supporting empirical research of such a cause and effect link from house prices to credit volume includes studies by Gerlach and Peng (2005) and Peng et al. (2008) ${ }^{18}$. Gerlach and Peng (2005) study the housing market of Hong Kong in the 1982 to 2001 period. Their cointegration analysis suggests that the property prices in Hong Kong are weakly exogenous, and the causality goes from property prices to bank loans. Peng et al. (2008) investigate the relationship between the property market and the macroeconomy in mainland China from 1998

\footnotetext{
${ }^{15} \mathrm{PM}_{2.5}$ measures the number of tiny particles with diameters less than 2.5 micrometers. Such particulate matters can enter deep into human lungs and cause potential cardiovascular and respiratory diseases. The recommended standard for $\mathrm{PM}_{2.5}$ in the U.S. is below 35.4 micrograms per cubic meter. If the measure rises beyond 210.5, the air quality is rated as hazardous.

${ }^{16}$ Lhasa in Tibet, the Hong Kong Special Administration Region, the Macau Special Administration Region, and cities in Taiwan are excluded.

${ }^{17}$ Two of the three protests occurred in July 2012, one in the eastern coastal city Qidong in Jiangsu Province, and one in Shifang in the south-western Sichuan Province. The third protest happened in October 2012, and was also in the eastern coastal city Ningbo.

${ }^{18}$ Among others, see Chen and Wang (2007) for loan-level evidence and more discussion of this point.
} 
to 2004, using panel data covering 25 provinces and six major cities. Their results show a twoway linkage between property price inflation and GDP growth. Furthermore, property price growth has a positive and significant effect on investment, especially real estate investment, but not on consumption. Thus, the causal relationship also seems to go from property price appreciation to credit expansion.

As the supply of housing stock is typically inelastic in the short run, an increase in bank credit may drive up house prices. Studies supporting this hypothesis include Mian and Sufi (2009), Collyns and Senhadji (2002), and Coleman IV et al. (2008). Mian and Sufi (2009) conduct a within-county analysis using detailed zip code-level data from 1991 to 2007. They find that mortgage credit grows unprecedentedly in subprime zip codes despite the relative income growth declines. Moreover, the negative relationship between mortgage credit and income is still significant in Metropolitan Statistical Areas (MSAs) with elastic housing supplies, implying that the subprime lending expansion is not due to lenders' expectations of higher future house prices. The authors suggest that the relative house price appreciation in subprime communities is the result of the increase in credit supply. Collyns and Senhadji (2002) report strong relations between credit growth and asset price booms in Indonesia, Malaysia, Philippines, South Korea, Thailand, Hong Kong, and Singapore. Using panel regressions and individual country VARs, the authors also argue for a credit channel to property price appreciation. Coleman IV et al. (2008) run a pooled cross-sectional analysis of 20 MSAs in the 1998-2006 period to investigate housing price dynamics. In the earlier years of their sample, economic fundamentals such as unemployment, population, income, and capital cost are found to be the primary driving forces of the house price dynamics. However, they lose significance towards the end of the observation period. The authors also discover that Government-Sponsored Enterprises (GSEs hereafter) are the main supplier of mortgage capital prior to 2004, whereas from late 2003 GSEs are squeezed out of the market by private issuers who wildly increase subprime lending. All of these studies suggest that credit expansion is the main driving force of house price appreciation, especially in the recent years.

Other studies find mixed evidence regarding the direction of causality. For instance, Wheaton and Nechayev (2008) use time series techniques to examine whether the appreciation of house prices between 1998 and 2005 can be explained by economic fundamentals. They 
estimate a single-stage univariate model for each of 59 U.S. MSAs from the 1970s to 1998, and then use actual economic data from 1998 to 2005 to forecast house prices. They find large magnitude of errors in the forecast. However, the explosive growth in credit availability brought about by the subprime lending, as well as the purchase of the second and investment home, predict the forecast error significantly. ${ }^{19}$

In addition to the literature on the link between house prices and bank credit, there is another strand of research in urban economics, compensating differentials, that is relevant to our study. Rosen (1979) and Roback (1982) lay down the basic framework for this line of research. They argue that people compete for amenable places to live, but as wages and home prices are adjusted to reflect spatially tied amenities, people have no incentive to move from one location to another. They set up a simple general equilibrium model to derive the comparative statics of wages and real estate prices. They also employ the hedonic pricing variant to test the hypothesis empirically. They find that housing prices are higher in cities with better amenities. However, the same is not necessarily true of wages. In their studies, pollution, extreme climate, and crime are documented as dis-amenities, and mild weather and, surprisingly, population density as desirable amenities. They construct a quality of life index using the implicit price estimates.

Building on Rosen and Roback's pioneer work, Blomquist et al. (1988) modify their model by including more than one county in each urban area to account for agglomeration effects. With a large cross-sectional dataset of 253 counties in 185 U.S. metropolitan areas, they derive new measures of quality of life, which reveal substantial variations both within and among urban areas. Their list of amenity variables is more extensive than that used in earlier research; it includes teacher-student ratio, violent crime rates, and even climate and environmental attributes. Gyourko and Tracy (1991) re-estimate the compensating differentials using the same census data as Blomquist et al. (1988). Although they shift the focus to central cities of metropolitan areas and work with an even longer amenities list including police, fire, health, education services, and local tax rates, their estimates of the characteristic variables, especially the pure amenities like climate, almost always bear the same signs as in Blomquist et al. (1988). Additionally, their study indicates that public safety, and fire and health services have

\footnotetext{
${ }^{19}$ In a cross-country study, Davis and Zhu (2011) also find a two-way relationship between bank lending and commercial property price using panel error correction model.
} 
a statistically significant effect on local wages. More recently, Shapiro (2006) demonstrates that human capital, as an indicator of local amenity, also has a causal effect on wages, rents, and house prices. But the author suggests that the influence on rents and home values is much larger than that on wages. ${ }^{20}$

The hypothesis that the concern for quality of life may rise with income, has inspired a growing number of studies on the compensating differentials in emerging markets. For example, Berger et al. (2008) apply the Rosen-Roback framework to Russian labor and housing markets. Their results are consistent with those found in developed countries, and confirm the applicability of the Rosen-Roback framework to transition economies. In addition to the traditional amenities such as climate, environment, crime rates, and health services, they also find that ethnic conflicts matter in Russia.

When it comes to the research on China's housing market, there have been many interesting studies as well. Leung and Wang (2007) apply the DiPasquale-Wheaton model to China and conduct policy analyses. Leung et al. (2011) propose simple models for house price and construction dynamics, and estimate model implications with data from four major cities. Shen (2012) develops a new housing affordability measure in terms of permanent income, and argues that housing affordability in China is fairly strong according to their new measure. Ren, Xiong, and Yuan (2012) test the existence of rational expectation bubbles. Wang, Yang, and Liu (2011) inspect how economic openness affects real estate prices. Liang and Cao (2007), Liang and Gao (2007), Peng et al. (2008), Zhang, Gong, and Bu (2006) contribute to the topic of interaction between bank lending and property market. However, these articles carry out their investigation at the national or provincial level. City-level research in this field has been rare due to data limitations. Deng et al. (2011) suggest a channel through which credit is poured into real estate investment by SOEs using land auction data from eight major cities. Their paper focuses on the land markets. With a manually collected dataset, we attempt to complement to the analysis of the relationship between bank loans and house prices from the disaggregated city level.

${ }^{20}$ Among others, see also Albouy (2009), Albouy et al. (2013), Glaeser (2008). 
Efforts have also been made to estimate compensating differentials in the context of China, including Zheng and Kahn (2008), Zheng, Fu, and Liu (2009), Zheng, Kahn, and Liu (2010), Zheng, Cao, and Kahn (2011), among others. Building on the same Rosen-Roback framework, Zheng and Kahn (2008) use two micro-datasets of land sales and project-wide house prices in Beijing to estimate the capitalization effects of local public goods. The authors find proximity to public transit, parks, core high schools, and universities all have significantly positive effects, and air pollution has a significantly negative impact on prices. Following Zheng and Kahn's (2008) early work on Beijing, Zheng, Fu, and Liu (2009) extend the research to 85 Chinese cities. Using China's Urban Household Survey, the authors perform a similar hedonic analysis of the amenity premium in 1998 and in 2004. This study incorporates more amenity variables than Zheng and Kahn (2008), such as climate and healthcare. The findings indicate a strong increase between 1998 and 2004 in urban resident's willingness to pay for amenities. Another study of compensating differentials by Zheng, Kahn, and Liu (2010) uses cross-city panel data from the 1997 to 2006 period. They document that green space and air pollution have significant effects on house prices, but in opposite directions. In contrast to Shapiro (2006), they find the effect of their measure of human capital insignificant. The effect of climate is also insignificant. Zheng, Kahn, and Liu (2010) contribute to environmental economics by establishing that FDI inflows reduce pollution levels. Zheng, Cao, and Kahn (2011) put even more weight on environmental economics; they study both air pollution production and its capitalization effect on real estate prices. The same 85 cities as in Zheng, Fu, and Liu (2009) in the 2006 to 2008 period are sampled, but an IV strategy is adopted to address the endogeneity of pollution. The authors find air quality and hospital beds have significant effects on house prices, but climate and teacher-student ratio do not.

Building on these authors' insights, this paper attempts to complement the literature by examining how a wide range of amenities are reflected in property prices, even after bank loans and other control variables are taken into account. Zheng and Kahn (2008) focus their analysis on Beijing. Zheng, Kahn, and Liu (2010) and Zheng, Cao, and Kahn (2011) concentrate on environmental issues. Zheng, Fu, and Liu (2009) mainly concern the compensating differentials in wages and housing rents. In addition, previous studies incorporate at most five aspects of amenities or disamenities. For each aspect, only one measure is adopted. The indicators of air pollution in these studies may serve as an illustration. Zheng, Fu, and Liu (2009) select sulphur 
dioxide emissions only, while in Zheng, Kahn, and Liu (2010) and Zheng, Cao, and Kahn (2011), the authors use particulate matter concentrations. However, both sulphur dioxide and particulate matter are important pollutants. Restricting their choice to either one means loss of information. Such practice is probably due to the concern that if more measures of the same amenity are included, estimation will be complicated by high collinearity among the measures (Ridker and Henning 1967). With the help of principal component analysis, we are able to mitigate the multicollinearity problem and include multiple measures for every amenity. In total, we incorporate 17 measures covering seven aspects of amenities or disamenities in this article: climate, air pollution, crime rate, health care, urban crowding, higher education, and green infrastructure, the last three of which are consolidated into one principal component.

\section{Data}

While previous studies on China's real estate market are interesting and inspiring, there are rooms for further improvement. First, they adopt the provincial level data in their research, which may combine information from both urban and rural areas. Their measure of real estate prices mixes residential, commercial, and industrial real estates. In addition, the composition and the relative importance of different types of real estates may vary across cities. Thus, a more disaggregated dataset with a price series exclusively focused on residential sector would provide more insights into China's municipal housing markets. In light of these considerations, we collect annual data for the 1999-2012 period for 35 major cities representing all the provinces in China except Tibet, the Hong Kong Special Administration Region, the Macau Special Administration Region, and Taiwan. Six cities including Haikou, Hohhot, Nanning, Shenzhen, Xining, and Yinchuan are excluded due to missing variables and data reliability problems. There is at least one city in the sample for most provinces, and for areas such as Liaoning, Fujian, Zhejiang, and Shandong province, there are two cities allowing for further analyses. These cities are scattered throughout China, and demonstrate large cross-sectional variations. Together, they represent China's geological, environmental, and social diversity.

The variables we collect can be divided into two groups. One group contains house prices, loans issued by the financial institutions of each city, per capita ${ }^{21}$ disposable income, long-term

\footnotetext{
${ }^{21}$ Variables involving population, such as per capita disposable income and population density, are calculated based
} 
interest rates, and stock market returns. As all of these variables are nominal, we convert them into real ones using city-level CPI and inflation rate ${ }^{22}$. The second group is variables for location-tied amenities. Specifically, we include local population density, the number of 211 Project universities in each city, green coverage ratio of each city, number of doctors and hospital sickbeds shared by every 10,000 people, number of suspects arrested or prosecuted by the local procuratorate every 10,000 people, the amount of yearly sunshine and precipitation, extreme temperatures, relative humidity, and the concentrations of $\mathrm{PM}_{10}, \mathrm{SO}_{2}$, and $\mathrm{NO}_{2}$ in the air. As the data come from various sources, we provide detailed variable descriptions and data sources in Appendix A. The descriptive statistics reported in Table 1 give an overview of how these variables evolve during the sampling period.

[Insert Table 1 about here.]

It is clear from Table 1 that real house prices, real bank loans, and real per capita disposable income all increased enormously as the economy developed ${ }^{23}$. Average real property prices and real per capita disposable income almost tripled. The real loans volume experienced a fivefold increase. Housing prices grew the fastest in $\mathrm{Ningbo}^{24}$, a beautiful coastal city in Zhejiang province, at an average growth rate of $13.6 \%$ throughout the sample period. Shenyang ${ }^{25}$ witnessed the slowest average growth rate, $4.9 \%$, in the same period. The growth rates in real bank lendings were much larger, around $15 \%$ in most cities in our sample. The fastest growth was in Changsha, Hefei, Ningbo, and Taiyuan, each of which had a rate of over $20 \%$. The growth rates in real income were similar to that of the house prices, but with smaller variances. Income in most cities grew at around 10\%. The income in Urumqi grew at the slowest pace (5.7\% annually). To avoid scale effect, we normalize loan volume by GDP. And since it is highly

on the population with "Hukou". The authors try to collect data on total population from municipal statistical yearbooks. But some cities choose to report total population, while others still report officially registered population only. The lack of consistency makes our efforts fruitless.

${ }^{22}$ There is currently no city-wide or province-wide fixed based CPI. We obtain the December CPI of each city with previous year as base from CEIC. City-level inflation rate is generated by CPI minus 100. Assuming the 1999 CPI equals to 100 for every city, we add the inflation rate back to derive an alternative CPI series.

${ }^{23}$ Note that in China, most bank loans are made by the four major, state-owned banks. Thus, the total bank loans are a sum of the loans made by private banks and state-owned banks. Our regional dataset, however, does not provide us with the information necessary to differentiate the two. See Geiger (2006) for more discussion of this problem.

${ }^{24}$ Zhejiang is one of the most advanced eastern provinces in China. Ningbo is the second most famous city in this province, and its importance is only second to the provincial capital, Hangzhou.

${ }^{25}$ Shenyang is the provincial capital of the north-eastern Liaoning province, which is economically less developed than Zhejiang province. 
likely that there exist long-run trends in these three series, we detrend these series in conjunction with deflating and logging.

For our amenity variables, we consider seven aspects: urban crowding, higher education, crime rates, health care, green space coverage, air pollution, and climate. Following the literature and considering data availability, we use per square kilometer population density to measure urban crowding, and green coverage ratio to represent local green infrastructure. The data collection methods for healthcare resources, air pollution, and climate are consistent with previous research, but we include more dimensions to capture more information. As we discussed earlier, the previous literature has examined the effects of particulate matter and sulphur dioxide. We include both pollutants, and add nitrogen dioxide ${ }^{26}$ due to its adverse health effects on human respiratory systems. For the same reason, we include the number of doctors and hospital sickbeds per 10,000 people as measures of the municipal healthcare resources. Our measures of climate include extreme temperatures, temperature difference ${ }^{27}$, amount of annual sunshine and precipitation, and relative humidity. Unfortunately, there is no crime data at the city level, so we use the number of suspects arrested and prosecuted by the local procuratorate per 10,000 population in each province as a proxy. These raw measures of air pollution, health care, climate, and crime rate are first treated with principal component analysis before entering the regression. The method will be discussed in detail in the next section.

While class size or student-teacher ratios in elementary schools are often used as measures of educational resources, we use the number of 211 Project universities by population in the municipality instead. There are at least three reasons for such a substitution. First, the locations of these universities are arguably more exogenous than other variables such as the average student-teacher ratio or class size. These universities were established a long time ago, and are not the product of recent economic developments ${ }^{28}$. Second, the variations are larger in tertiary education than in primary and secondary education. There are 26 universities in Beijing that are funded by "Project 211", ten in Shanghai, eight in Nanjing, seven in Wuhan, seven in

\footnotetext{
${ }^{26}$ The health effects of nitrogen dioxide can be found on the website of the United States Environmental Protection Agency: http://www.epa.gov/oaqps001/nitrogenoxides/health.html.

27 The temperature difference is defined as (maximum temperature - minimum temperature) ${ }^{2} / 100$.

${ }^{28}$ In fact, it is well-known that increasing teachers' salaries or reducing student-teacher ratios do not necessarily lead to "better" education outcome. See Hanushek (2006, 2009). In addition, Hanushek and Yilamz (2007) analyze household mobility when school qualities differ across communities.
} 
Xi'an, one in most other major cities, and none in Ningbo and Shijiazhuang. And finally, living around a key higher education institution means beneficial exposure to well-educated peers and easy access to university campus where large open space, sports facilities, and libraries are available. In fact, Zheng and Kahn (2008) have demonstrated that proximity to major universities is a desirable feature for home-buyers, whereas the insignificance of student-teacher ratios is documented by Zheng, Cao, and Kahn (2011).

Our panel dataset might have an additional merit. Some previous studies on the relationship between amenities and house prices focus on the cross-sectional differences. While these cross-sectional differences are clearly important, it might overlook the fact that local amenities do change over time. For instance, the health care provision in many cities improves over the sample period, especially in Changsha, Chengdu, Guangzhou, Hangzhou, and Jinan. Some places have cleaner air (e.g., Chongqing, Kunming, Nanjing, Wuhan, etc.) in the sense that the pollutant emissions are reduced as time passes by. At the same time, public security has been deteriorating in all cities. One possible explanation is that the growing income gap between the rich and the poor drives up the expected benefit of committing a crime. We provide a visualization of the increase of hospital beds in our sampled cities from 1999 to 2012 in Figure 4. Appendix E reserves more details about the temporal change in amenities for interested readers. These "stylized facts" further reinforce the view that amenities would change with income and therefore it is important to adopt a unifying framework including both amenities and bank loans to study the house prices in different cities.

[Insert Figure 4 about here.]

\section{Empirical Framework}

\subsection{Principal Component Analysis (PCA)}

A typical challenge for empirical research on local amenities is that we either do not include enough measures of the amenities, or we do have many measures and yet multicollinearity exists among them, which makes the econometric results a bit difficult to interpret. For example, indicators for climate, such as the amount of precipitation and relative humidity, are naturally highly correlated. The same is true for other amenities. Such 
multicollinearity has been documented by Ridker and Henning (1967). When all of our amenity measures are included in the regression analysis, most of them are insignificant and display counterintuitive signs. Simply dropping some will result in the loss of valuable information. To mitigate the multicollinearity problem while preserving the information in the data, we use principal component analysis ${ }^{29}$, a popular statistical method that reduces the data dimensionality and at the same time retains as much variance as possible.

The PCA recommends preserving five principal components out of 17 raw measures. These five components jointly account for over $70 \%$ of the total variance. Each component can be thought of as a weighted sum of the standardized amenity variables with scoring coefficients in Table 2 as weights. Since most weights are assigned to minimum temperature, temperature difference, sunshine, and humidity, we can roughly regard component 1 as climate indicator. By the same token, component 2 measures air pollution, component 3 stands for crime rate, and component 4 represents local healthcare condition. Each component proxies one kind of amenity except the last one, which mixes urban crowding, higher education, and local green infrastructure together. We term component 5 social development.

[Insert Table 2 about here.]

\subsection{Two-step Regression Analysis}

Although PCA is adopted to mitigate the multicollinearity problem, a simple regression with PCA-consolidated variables may still fail to give accurate estimates of the effects of local amenities, as those amenities may affect house prices directly as well as indirectly by changing the local income. To have a better understanding of the mechanism through which amenities affect the house price, our regression analysis is conducted in two steps. First, we regress the log transformed and detrended real income on local amenities and retain the residual. The residual could be interpreted as the "filtered income", i.e. the income that is not predicted by local amenities. We put this residual term together with other explanatory variables into the secondstep regression to get more consistent estimates of income and amenity variables.

Step 1:

\footnotetext{
${ }^{29}$ Principal component analysis and related methods have been used widely in previous studies. See Jolliffe (2010) for a review of the literature on this subject.
} 
Income $_{i, t}=b_{0}+X_{i, t} b+e$

Income is the log transformed and detrended real per capita income. $X$ is the row vector of five principal components including climate, air pollution, crime rate, health care, and social development. Although some of these amenities may not be strictly exogenous, they can be considered as predetermined (Keane and Runkle, 1992). The amenities level, such as health care provision, is the result of past fiscal policies, and is presumably independent of future income shocks. According to Greene (2012), predetermined variables can be treated "as if they were exogenous in the sense that consistent estimates can be obtained when they appear as regressors. ${ }^{30} \mathrm{We}$ calculate the residual from the regression (the part of income unexplained by amenities) and denote it as the filtered income. The subscript $i$ is an index for city, $t$ for year.

Step 2:

House Price ${ }_{i, t}$

$$
\begin{aligned}
& =\beta_{0}+\beta_{1} \text { Loan }_{i, t-1}+\beta_{2} \text { Filtered Income }_{i, t}+\beta_{3} \text { Interest Rate }_{i, t} \\
& +\beta_{4} \text { Stock Market Return } \\
& i, t \\
& +X_{i, t} \beta_{5}+\varepsilon
\end{aligned}
$$

House Price is the log transformed and detrended real housing prices. Loan is the detrended loan GDP ratio. Filtered Income is the residual from the first-step regression. Interest Rate is the real long-term borrowing rate, and serves as the proxy for mortgage rate. Stock Market Return is the current-value-weighted aggregated market returns with cash dividend reinvested. It is included since the stock market return may reflect the market sentiment or represent the future productivity growth ${ }^{31} . X$ is the same row vector of amenities as in the first step. In order to tackle the cross-sectional heterogeneity in Chinese cities, we also include the regional dummies. Each city is placed in one of the four categories, i.e., northeast, east, west, and central China, according to the division criterion of the NBSC. A similar practice has been adopted by other authors.

For the purpose of alleviating the endogeneity problem, we include the one-year-lagged instead of contemporary Loan in the second-step regression. Limited by the sample size, we can afford to consider one lag only. In order to justify our approach of combining bank loans and

\footnotetext{
${ }^{30}$ We will show in section 6.3 that endogeneity in these produced amenities may not be a serious issue in the current sample. For more discussion on endogeneity issue in econometrics, see Angrist and Pischke (2010), Sims (2010), among others.

${ }^{31}$ See Greenwood and Jovanovic (1999), Hobijn and Jovanovic (2001) for more discussion.
} 
local amenities in one framework, we conduct model comparison by carrying out three housing price regressions, all with $\log$ transformed and detrended real house prices as dependent variable. The first regression includes macroeconomic variables as regressors. The second regression includes urban amenities as controls. And the third regression integrates both, the specification of which is provided in Equation (2). The goodness-of-fit statistics of the three empirical models are summarized in Table 3. Compared with the first two columns, the third has the highest adjusted R-squared and F-statistic, the lowest AIC, BIC, and root mean squared error (RMSE). And as will be shown by the same regression on standardized variables in column (2) of Table 4, apart from the lag term of bank credit, urban amenities also have larger standardized coefficients than some macroeconomic variables, which means amenities have relatively greater impacts on detrended real house prices than filtered income, long-term interest rate, and stock market return. Together with the significant interaction between loans and amenities to be reported in Table 7, these evidence suggest that the specification in Equation (2) is a better empirical model.

\section{[Insert Table 3 about here.]}

Since housing prices within the same city tend to be correlated over the years, it is prudent to use clustered standard error to deal with the possible intra-class correlation. On the other hand, clustering analysis tends to inflate the standard errors even more than heteroskedasticity robust standard errors. The statistical significance of the point estimates are expected to be affected.

\subsection{The Reversed Effect of House Prices on Loans}

To inspect the effect of house prices on credit, we run the loan regressions. ${ }^{32}$ Following Peng et al. (2008), fixed asset investment is included to capture the investment demand for bank credit. The stock market return is taken into account for two reasons. During a hot stock market, on the one hand, as households draw deposit from banks to invest in the stock market, the banks will have to reduce the loan supply. On the other hand, firms also turn to the stock market as an alternative financing source. Both reasons suggest the loan volume may be negatively related to the stock market return. We fit the loan equation with a fixed effect model.

\footnotetext{
${ }^{32}$ In this regression, income enters the right hand side without filtering.
} 


$$
\begin{gathered}
\text { Loan }_{i, t}=\gamma_{0}+\gamma_{1} \text { House }_{\text {Price }} \text { H }_{i-1}+\gamma_{2} \text { Income }_{i, t}+\gamma_{3} \text { Fixed Asset Investment }_{i, t} \\
+\gamma_{4} \text { Interest Rate }_{i, t}+\gamma_{5} \text { Stock Market Return }_{i, t}+\mu
\end{gathered}
$$

Fixed Asset Investment refers to the annual fixed asset investment over GDP ratio. Other variables carry the same definition as in Equation (1) and (2). Contemporary House Price is replaced by its one-period lag to address the endogeneity concern.

\section{Empirical Results}

\subsection{Main Results}

As previously discussed in Section 5.2, we fit three empirical models for housing prices to facilitate model comparison. The findings from the full model which combines bank loans and urban amenities in one unifying framework will be discussed in detail in this section. Results of the other two models are reserved in Appendix B. To justify our use of the PCA technique, we perform a regression with the raw amenity measures and provide the results in Appendix B as well. Regression output with PCA-consolidated amenity variables and unfiltered income can also be found in Appendix B.

Our discussions begin with the outcome of the second-step regression with PCA technique applied on the full sample from 1999 to 2012. Column (1) of Table 4 reports the point estimates and their associated p-values. Column (2) documents corresponding standardized coefficients. Since standardized coefficients inherit the same statistical significance as point estimates, we omit the p-values and significance stars in column (2). In the full-sample outcome, the elasticity of the house prices with respect to the detrended and filtered real income is 1.017, which indicates the detrended real housing prices would be $1.017 \%$ higher if the income increases by $1 \%$. In terms of standardized coefficient, real property prices will rise by 0.324 standard deviations if the income goes up by one standard deviation. Such effect is statistically discernible from zero at the $1 \%$ significance level. The coefficient of real stock market return on real house price is around 0.021 , which is statistically significant at the $1 \%$ significance level. This confirms previous findings that the stock market and housing market tend to co-move. ${ }^{33}$ However, the coefficient estimate of the normalized loan is not significantly different from zero,

\footnotetext{
${ }^{33}$ Among others, see Leung (2007) on the relationship between the stock market and the housing market in equilibrium.
} 
detailed discussion of which will be provided in the subsample analysis. The long-term interest rate is not significant either.

[Insert Table 4 about here.]

Column (1) of Table 4 also shows that estimates for crime rate and the principal component representing higher education, green space coverage, as well as urban crowding are highly significant at the $1 \%$ significance level. All amenities except crime rate display the anticipated signs. A comparison with Table B4 confirms our conjecture that income is not completely exogenous. Cities with more desirable amenities would attract people with higher abilities and incomes. Statistically speaking, we need to adopt a 2-stage procedure to address such "implicit selection". Notice that the point estimates are elasticities of house prices with respect to corresponding component score. The interpretation should be how a one-score change in the principal component would influence the property prices. For example, an improvement of one score in the social development component would push house prices up by $12.8 \%$. One standardized deviation increase in the social development indicator would result in 0.401 standardized deviations appreciation in the housing prices. Recall the social development component is made up of higher education, green infrastructure, and urban crowding. Our findings are consistent with existing evidence. The premium for green infrastructure has been previously documented by Zheng, Fu, and Liu (2009), and Zheng, Kahn, and Liu (2010), while similar positive influence of education or human capital can be found in Blomquist (1988), Gyourko and Tracy (1991), Zheng, Fu, and Liu (2009). Our paper is closest to Zheng and Kahn (2008) in the sense that both inspect the impact of higher education. Conventionally, a higher population density implies crowding and should suppress house prices. However, recent studies suggest that a more concentrated population may be associated with better learning and matching in the labor market (Laing et al., 1995; Bleakley and Lin, 2012), better matching in the marriage market (Gautier et al., 2010), more product variety (Schiff, 2012), etc. Thus, a higher population density can have a positive effect on house prices. In fact, Roback (1982) also documents a significantly positive influence of population density on residential site prices. We believe the same reasoning applies to public security. Great and economically successful cities usually also breed more crime. The positive capitalization effect of crime is also reported by Blomquist et al. 
(1988), Gyourko and Tracy (1991), and Berger et al. (2008). The amenity variables capture the location heterogeneity well so that regional dummies are no longer significant.

Running regression on standardized variables, we directly compare coefficients to assess the relative strengths of corresponding variables in explaining the variance in housing prices. In column (2), one-year lag of normalized credit has a standardized coefficient of 0.094, and real income 0.324 . Among all the explanatory variables, the long-term interest rate has the smallest standardized coefficient, -0.008 , which means one standard deviation increase in the interest rate almost does not alter the property prices. All the amenity components have greater standardized coefficients than the mortgage rate proxy do. The standardized coefficients of social development and crime rate are even larger than those of bank lending and income. Clearly such comparison is possible only when both bank loans and urban amenities are included in a unifying framework.

To investigate how housing prices may influence loans, we fit equation (3) to data using fixed effect method and report the estimation results in column (1) of Table 5. As the column shows, home price lag significantly and positively affects loan GDP ratio. The point estimate is 0.53 , and the standardized coefficient is 0.414 . In plain language, $1 \%$ appreciation in the property price would induce the future credit volume to expand by 53 basis points, while one standard deviation increase in the property price would correspond to 0.414 standard deviation increase in bank lending in the following year. The impact of the normalized fixed asset investment is larger in elasticity, but smaller in terms of standardized coefficient. If the fixed asset investment over GDP ratio is higher by $1 \%$, the demand for bank loans would be almost $1 \%$ greater. If the fixed asset investment goes up by one standard deviation, the credit would grow by 0.356 standard deviations. The first instinct about interest rate, a measure of borrowing cost, is that higher interest rate should suppress borrowing. However, a more careful reasoning casts doubt on this simple intuition. Interest rate is an endogenous variable. When there is huge demand for capital, the borrowing cost will naturally climb up. And when the economy "overheats", the central bank will also raise the interest rate to cool it down. As a result, we observe a positive relationship between the interest rate and the credit ${ }^{34}$. Our negative estimate of

\footnotetext{
${ }^{34}$ It may take a more structural model to investigate the relationship between interest rate and property market formally and hence we leave this for future research.
} 
the real stock market return is evidence of our conjecture that stock is another investment vehicle to households, and the stock market is an alternative financing source to firms. Despite being statistically insignificant, the estimate for detrended real income is of a negative sign, which echoes the finding of Peng et al. (2008). Cities with higher income tend to have more diversified financing channels and rely less on bank loans.

\section{[Insert Table 5 about here]}

\subsection{Subsample Analysis}

As is shown in Figure 1 and Figure 3, both house prices and loans have gone through several different stages. It is therefore natural to wonder whether our results derived from the full sample also hold in different sub-samples. In this section, we will discuss our findings for subsamples.

Due to the limitation of sample size, we can only afford to divide the whole sample into two subsamples, which are Before the Great Recession, and After. A further attempt to break the pre-crisis subsample into before and after 2003 will result in too few observations for the period prior to 2003. As our sample begins in 1999, the first subsample (i.e. Before the Great Recession) has more observations than the second one. In fact, both the qualitative and quantitative results for the period between 1999 and 2008 are very similar to those in the full sample. Therefore, we will put more effort into documenting the findings for the post-recession era.

In the housing price regression for the data after 2008 reported in column (5) and (6) of Table 4, we find that bank credit plays a significant role in driving up home prices, which is consistent with Liang and Cao (2007), and Liang and Gao (2007). Furthermore, the magnitudes of both point estimate and standardized coefficient are larger compared to the results in the other columns of Table 4. To be more specific, if the loan GDP ratio goes up by $1 \%$, the house prices in the following year would appreciate by 16.1 basis points. And one standard deviation increase in the current financial institutional lending would lead to a 0.179 standard deviations growth in the real house price in the next year, with everything else held constant. In contrast, the coefficient on the real income changes in the opposite direction. Both the coefficient values and the statistical significance decline. The influence of the stock market return becomes insignificant as well. We believe such failure of precise estimation is caused by the small amount 
of identifying variance (Griliches and Mairesse, 1995) in the stock market return from 2009 to 2012. The other variables have the same pattern as documented in the last section.

In sum, we find the bank lending has contributed to the property price inflation in a time of easy credit, but not before. Nevertheless, the pattern of statistical significance is reversed in the case of how the real estate prices have influenced the loan volume. From 1999 to 2008, our estimate suggests that the housing prices significantly and positively affected the loan GDP ratio, rather than the other way around. Peng et al. (2008) reached the same conclusion for the period from 1998 to 2004. In the second sub-sample, the impact from the previous year real house price on bank loan switches from significant to insignificant. Even income does not appear to have any power in explaining loans after the Great Recession. Again probably because of the reduced amount of variations in the interest rate and stock market return, their estimates lose significance as well in the second subsample. The only statistically significant variable is the normalized fixed asset investment. In spite of this, the adjusted R-squared surprisingly jumps to 0.97 in column (5). Putting the small sample issue aside, the results here are in fact consistent with a recent literature, which suggests that the "Stimulus Package" implemented by the Chinese government after the Great Recession, which tends to focus on fixed asset investment, may play a key role in explaining the bank loans in China. ${ }^{35}$

\subsection{Endogenous Amenities}

This section shifts the attention to amenities. Obviously, some amenities are completely exogenous such as climate, while others are not. Urban crowding, green infrastructure, public health care, crime rate, and air pollution are produced by human society (Rosen 1979; Roback 1982; Blomquist et al. 1988; Gyourko and Tracy 1991), and may not be strictly exogenous. Thus, to examine the effect of amenities on the house prices, one needs to address such endogeneity concern. In this section, we conduct the same two-step analysis on amenities as we do on income. Notice that our amenity variables are linear combinations of all raw amenity measures, and thus there is measurement error in them when they are viewed as indicators of amenities. For example, component 1 is mostly about climate, but it also contains other information, and cannot be thought of purely exogenous. We therefore apply the filtering process to every component. We

\footnotetext{
${ }^{35}$ Clearly, it is beyond the scope of this paper to survey this growing literature on the impact of the post-crisis response of China. Among others, see Csanadi et al. (2013), Garcia-Herrero and Santabarbaram (2011), IMF (2014), Wong (2011).
} 
regress the produced amenities against detrended real income and retain the residuals as "filtered" amenities in the first step, which are then inserted into the second-step regression together with the other variables specified in equation (2).

Overall, our findings are not weakened by this "cleaning procedure" applied to the amenity variables. Regarding how the bank loans have affected the housing prices, the results remain the same as in Table 4. The empirical results on how amenities affect house prices actually become sharper. Due to such similarities, we focus our discussion on the post-recession estimation reported in column (5) and (6) of Table 6. After removing the "endogenous component of amenities", the effect of income on home prices is much greater. If one city is richer than another by $1 \%$ of filtered income, it would also have the house prices higher by $3.792 \%$. Such a huge effect is not unlikely if housing is considered as a "luxurious good" by the households. Then an increase in income would lead to a higher proportion of expenditure share on housing in the total budget. Since the housing supply is quasi-fixed in the short run, an increase in the expenditure share will be translated into a higher housing price at the equilibrium. Among the amenities, social development and crime rate are still highly significant. Now, other amenity components also become significant. The standardized coefficient of the climate component is 0.369 , which is larger than that of the normalized loan and almost four times of the previous estimate for climate in Table 4.

Notice that such an important impact of climate we have obtained is different from what Zheng, Kahn and Liu (2010) and Zheng, Cao, and Kahn (2011) have found. These two studies documented a negligible climate effect. The difference of the results may be due to the measurement issue. These studies measure climate by a function of temperatures, while this paper includes a more inclusive measure through the principal component method. Thus, our result may suggest that other aspects of climate such as sunshine, precipitation, and relative humidity matter for the housing market. In addition to climate, the healthcare component has become marginally significant as well. The associated standardized coefficient has also grown from 0.018 in Table 4 to 0.078 in Table 6, an over three times' increase. This finding about the importance of local healthcare condition is consistent with existing literature. Zheng, Fu, and Liu (2009) show that people are willing to pay a positive rental premium for more doctors in town. 
Zheng, Cao, and Kahn (2011) have documented the number of sickbeds in hospitals and clinics positively affect newly-built house prices.

[Insert Table 6 about here]

\subsection{Interaction Effects}

We have argued that loans and some amenities may interact with each other through their relations to a common third variable. In this section, this thesis is examined more formally. More specifically, we incorporate the interactive terms of loans and other variables in the estimation. The new regression becomes

House Price $e_{i, t}$

$$
\begin{aligned}
& =\beta_{0}+\beta_{1} \text { Loan }_{i, t-1}+\beta_{2} \text { Filtered Income }_{i, t}+\beta_{3} \text { Interest Rate }_{i, t} \\
& +\beta_{4} \text { Stock Market Return }_{i, t}+X_{i, t} \beta_{5}+\text { Loan }_{i, t-1} X_{i, t} \beta_{6}+\varepsilon
\end{aligned}
$$

Overall, this regression supports the position that credit and amenities are indeed interrelated. Here are more details. Compared with Table 6, the goodness of fit improves in Table 7. The estimate for the loan GDP ratio gains significance even in the full sample. The amenity variables remain as significant as in Table 6. More importantly, the interaction effects between climate, health care, crime rate and bank lending are statistically significant, with signs in line with our expectation. The multiple of social development and bank lending is almost significant as well. Notice that bringing in interactive terms in the regression demands more cautions in the interpretation of the results. Here are our interpretations. The influence of credit on housing prices now varies across the level of amenity. The negative coefficients on the interactive terms suggest that home prices are less sensitive to credit expansion in cities with better amenities such as more pleasant climate, more green space coverage, better health care and higher education. In addition to the full-sample results, we also briefly review the subsample findings. From 1999 to 2008 , the main effect of the normalized loan is statistically indistinguishable from zero, the same as the overall effect in column (3) of Table 6. Though the main effects of amenities are very similar to their full-sample counterparts in column (1) of Table 7, the interactive terms seem to become more important in the econometric model. In fact, after 2008, only the interactive term of pollution and loan ratio is significant. The statistical significance of other interactive terms 
could be "reduced" due to the small sample issue. We can only wait for future research to confirm this speculation.

[Insert Table 7 about here]

\subsection{Panel Estimation}

To further exploit our dataset which has both cross-sectional and temporal variations, we perform additional panel data estimation. Consistent with our previous results, the impact of credit on house price is found to be significant only after the Great Recession. Therefore, to save space, we limit our discussion to the post-recession results in this section. The fixed effect model has the advantage of allowing the unobserved individual effects to be correlated with the covariates. The tradeoff is "using the most restricted amount of variance for the identification of the various coefficients" (Griliches and Mairesse, 1995). In our case, we run the Hausman test to determine whether random effect or fixed effect model should be adopted. The Hausman test does not reject the consistency of the random effect model for the data after 2008. We present the results from the fixed effect model as well. ${ }^{36}$

The first two columns of Table 8 report the fixed effect and random effect estimations of equation (2), corresponding to the last two columns of Table 4. The two columns in the middle of Table 8 are the panel estimation counterparts of column (5) and (6) in Table 6. And the last two columns of Table 8 can be compared to those in Table 7. After a comprehensive comparison, we find the random effect estimates of the lagged normalized loan are very close to previous ones. Although the within transformation reduces the amount of variance in data, the coefficient on the loan variable is still significant in column (5) of Table 8, and is marginally significant in column (1) and (3). However, the same parameter is slightly bigger in the fixed effect model than in the random effect model. When it comes to the real income, the random effect estimates are greater than the ordinary least squares estimates. The fixed effect estimates of income are quite different across the three specifications. Unlike previous regressions, the coefficients of interest rate become statistically significant, and carry stable values using either the fixed effect or the random effect estimator. The negative sign further suggests that interest rate has an impact on the

\footnotetext{
${ }^{36}$ As we present the earlier version of this paper in different conferences, there are audiences interested in the findings from the fixed effect model. For a more engaging discussion of the fixed effect model and the random effect model, see Hsiao (2003).
} 
housing price. Among the amenity variables, both the significance pattern and the magnitude of the significant estimates are similar to those in Table 4, 6, and 7. The interaction effects are more significant in the full sample, just the same as the case in Table 7.

[Insert Table 8 about here]

\section{Conclusions}

As the world economy struggles to move out of the recession, the Chinese economy can no longer depend on the driving force of exports to prevent it from slowing down. In fact, some developed countries are expecting to export their goods and service to China. If the Chinese real estate market crashes at this time, China and many of her trading partners would suffer serious setbacks; this scenario is of great concern to both researchers and the general public ${ }^{37}$. Most of the existing research on the relationship between credit expansion and house price surge relies on aggregate data at the provincial or national level, leaving out the issues caused by geographical heterogeneity. This study uses a unique, hand-collected city-level dataset to take the first step in assessing the interactions among bank loans, property prices and local amenities. Since both credit and amenities influence house prices, and since the effects of these two factors are interacted, we combine them in one simple yet unified framework. And our model has the capability to evaluate the relative importance of different factors.

To conclude our findings, the housing prices had significantly affected the financial institutional lending before the Great Recession, whereas after the crisis the loan expansion has been an important force driving up the home prices. When the real property prices went up by $1 \%$ before 2008 , the loan GDP ratio would be greater by almost 50 basis points in the next year according to our estimate. If instead the house prices experienced an increase of one standard deviation, the future normalized loan would expand by 0.371 standard deviations. On the other hand, in the post-recession era, $1 \%$ incremental change in the loan ratio would boost the real property prices by 16.1 basis points in the following year. In terms of standardized coefficient, an increase of one standard deviation in the loan ratio would lead to a growth of 0.179 standard deviations in the future house prices. Such empirical results imply that although the loans were

\footnotetext{
${ }^{37}$ See Economist (2013) for a special report on this topic.
} 
once truly demanded by the market, they begin to influence the asset prices when an enormous amount of them are poured into the economy. Besides bank lending, local amenities such as climate, health care, higher education, and green space coverage are also capitalized into house prices. And the amenities' impacts are by no means weaker than that of the credit. For example, the standardized coefficients of climate and social development (the composite component of population density, higher education, and green infrastructure) are 0.357 and 0.71 respectively. Both are greater than that of the bank lending, which is 0.179 . Comparing our results with the literature also suggests that "climate" is more than temperature. Sunshine, precipitation, and relative humidity all matter for the housing market. The healthcare indicator has a standardized coefficient of 0.075 , also larger than that of the interest rate (0.06) and the stock market return (0.057). Last but not the least, the credit and some amenities including climate, crime rate, health care, and social development are negatively interacted with each other, suggesting that property prices are less sensitive to lending growth in cities with more desirable amenities.

The evidence we have documented is likely to carry important policy implications. First, monetary policy is important for the house price stability as it would impact the credit expansion. Since the major banks in China are all national banks, bank credit is indeed a part of the monetary policy. Second, the local government investment in amenities can lead to increase in house prices. One possible reason for why amenities affect property prices is that cities offering high quality of life can attract immigrants, whose living needs push up housing demand much more than the supply is able to adjust. Apart from contributing to home price, the influx of new labor, especially the high quality human capital, is beneficial for promoting productivity of the city as well (Peri, 2012). On the other hand, amenities via housing demand can influence local land sale revenue, which in the current context of China is an important determinant of local government financial position.

One limitation of our study is there may be concern for external validity. The current sample covers only relatively developed cities in China with more active financial markets. The link between the bank credit and the housing market may be stronger in these cities. As urbanization is still an undergoing process for China, meaning that small and medium cities of today could become big cities in the future. Understanding the housing market, urban amenities, and government policy could be very important. Thus, this study may also shed light on those 
emerging cities. In addition, the China experience may shed light for other developing countries as well. ${ }^{38}$

Clearly, our analysis is far from being the last word on this issue. Household-level data and the mortgage loan data, when become available, should be used to confirm our tentative conclusion. Since there has been evidence of improved regional capital mobility in China as the economy develops (Chan et al., 2011), future research could also investigate whether there exists spatial spillover among regional housing markets, and what role does regional capital flow play in such spillover effect.

${ }^{38}$ Clearly, it is beyond the scope of this paper to survey the literature on the urbanization in developing countries. Among others, see Glaeser (2014), Malpezzi (2012), Romer (2014). 


\section{Reference}

Albouy, D., 2009. What are cities worth? Land rents, local productivity, and the capitalization of amenity values, NBER Working Paper 14981.

Albouy, D., F. Leibovici, C. Warman, Quality of life, firm productivity, and the value of amenities across Canadian cities, Canadian Journal of Economics, 46, 379-411.

Angrist, J.D., Pischke, J.S., 2008. Mostly harmless econometrics: An empiricist's companion. Princeton University Press, Princeton.

Angrist, J.D., Pischke, J.-S., 2010. The credibility revolution in empirical economics: How better research design is taking the con out of econometrics. Journal of Economic Perspectives $24,3-30$.

Berger, M.C., Blomquist, G.C., Sabirianova Peter, K., 2008. Compensating differentials in emerging labor and housing markets: Estimates of quality of life in Russian cities. Journal of Urban Economics 63, 25-55.

Bleakley, H., Lin, J., 2012. Thick-market effects and churning in the labor market: Evidence from US cities. Journal of Urban Economics 72, 87-103.

Blomquist, G.C., Berger, M.C., Hoehn, J.P., 1988. New estimates of quality of life in urban areas. The American Economic Review 78, 89-107.

Chan, K.S., Dang, V.Q., Lai, J.T., Yan, I.K., 2011. Regional capital mobility in China: 19782006. Journal of International Money and Finance 30, 1506-1515.

Chang, K.L., Chen, N.K., Leung, C.K.Y., 2011. Monetary policy, term structure and asset return: comparing REIT, housing and stock. Journal of Real Estate Finance and Economics 43, 221-257.

Chen, N.K., Wang, H., 2007. The procyclical leverage effect of collateral value on bank loans: evidence from the transaction data of Taiwan. Economic Inquiry 45, 395-406. 
Coleman IV, M., LaCour-Little, M., Vandell, K.D., 2008. Subprime lending and the housing bubble: Tail wags dog? Journal of Housing Economics 17, 272-290.

Collyns, C., Senhadji, A., 2002. Lending booms, real estate bubbles, and the Asian crisis, IMF Working Paper.

Costa, D.L., Kahn, M.E., 2003. The rising price of nonmarket goods. American Economic Review 93, 227-232.

Csanadi, M., Z. Nie, S. Li, 2013. Crisis, stimulus package and migration in China, mimeo.

Davis, E.P., Zhu, H., 2011. Bank lending and commercial property cycles: Some cross-country evidence. Journal of International Money and Finance 30, 1-21.

Davis, M.A., Fisher, J.D., Whited, T.M., 2014. Macroeconomic implications of agglomeration. Econometrica 82, 731-764.

Deng, Y., Morck, R., Wu, J., Yeung, B., 2011. Monetary and fiscal stimuli, ownership structure, and China's housing market, NBER Working Paper.

Gabriel, S.A., Mattey, J.P., Wascher, W.L., 2003. Compensating differentials and evolution in the quality-of-life among US states. Regional Science and Urban Economics 33, 619-649.

Garcia-Herrero, A., Santabarbaram, D., 2011. China's banking system risks after the 2008-10 stimulus package and the housing boom, BBVA, mimeo.

Gautier, P.A., Svarer, M., Teulings, C.N., 2010. Marriage and the city: Search frictions and sorting of singles. Journal of Urban Economics 67, 206-218.

Geiger, M., 2006. Monetary policy in China (1994-2004): Targets, instruments and their effectiveness, SSRN Working Paper.

Gerlach, S., Peng, W., 2005. Bank lending and property prices in Hong Kong. Journal of Banking \& Finance 29, 461-481.

Glaeser, E.L., 2008. Cities, agglomeration, and spatial equilibrium. Oxford University Press, New York. 
Glaeser, E.L., 2014. Cities in the developing world. Paper presented in the 2014 World Bank Conference on Urbanization and Development.

Glaeser, E.L., Gyourko, J., 2007. Arbitrage in housing markets, Harvard University Working Paper.

Goldberger, A.S., 1991. A course in econometrics. Harvard University Press, Cambridge.

Goodhart, C., Hofmann, B., 2007. House prices and the macroeconomy. Oxford University Press, New York.

Goodman, A.C., 1988. An econometric model of housing price, permanent income, tenure choice, and housing demand. Journal of Urban Economics 23, 327-353.

Greene, W.H., 2012. Econometric analysis. Prentice Hall, Boston.

Greenwood, J., Jovanovic, B., 1999. The information-technology revolution and the stock market. American Economic Review 89, 116-122.

Griliches Z., Mairesse J., 1995. Production functions: the search for identification, NBER Working Paper.

Gyourko, J., Kahn, M., Tracy, J., 1999. Quality of life and environmental comparisons, in: Cheshire, P., Mills, E.S. (Eds.), Handbook of Regional and Urban Economics, Vol. 3. North Holland, Amsterdam, pp. 1413-1454.

Gyourko, J., Tracy, J., 1991. The structure of local public finance and the quality of life. Journal of Political Economy, 774-806.

Hanushek, E.A., 2006. School resources, in: Hanushek, E.A., Welch, F. (Eds.), Handbook of the economics of education, Vol. 2. North Holland, Amsterdam, pp. 865-908.

Hanushek, E.A., 2009. School policy: Implications of recent research for human capital investments in South Asia and other developing countries. Education Economics 17, 291 313. 
Hanushek, E., Yilmaz, K., 2007. The complementarity of Tiebout and Alonso. Journal of Housing Economics 16, 243-261.

Hanushek, E.A., Yilmaz, K., 2010. Household location and schools in metropolitan areas with heterogeneous suburbs: Tiebout, Alonso, and government policy, NBER Working Paper.

Hobijn, B., Jovanovic, B., 2001. The information-technology revolution and the stock market: Evidence. American Economic Review 91, 1203-1220.

Hsiao, C., 2003. Analysis of panel data. Cambridge University Press, Cambridge.

IMF, 2014. Global Financial Stability Report (October), Washington, D.C.

Jolliffe, I., 2005. Principal component analysis. Springer-Verlag, New York.

Keane, M.P., Runkle, D.E., 1992. On the estimation of panel-data models with serial correlation when instruments are not strictly exogenous. Journal of Business \& Economic Statistics $10,1-9$.

Kiyotaki, N., Moore, J., 1997. Credit cycles. Journal of Political Economy 105, 211-248.

Kwan, Y.K., Dong, J., 2014. Stock price dynamics of China: A structural estimation approach. Emerging Markets Finance and Trade, forthcoming.

Laing, D., Palivos, T., Wang, P., 1995. Learning, matching and growth. Review of Economic Studies 62, 115-129.

Leung, C.K.Y., 2007. Equilibrium correlations of asset price and return. Journal of Real Estate Finance and Economics 34, 233-256.

Leung, C.K.Y., Chow, K.K., Yiu, M.S., Tam, D.C., 2011. House market in Chinese cities: Dynamic modeling, in sample fitting and out-of-sample forecasting. International Real Estate Review 14, 85-117.

Leung, C.K.Y., Wang, W., 2007. An examination of the Chinese housing market through the lens of the DiPasquale-Wheaton model: A graphical attempt. International Real Estate Review 10, 131-165. 
Liang, Q., Cao, H., 2007. Property prices and bank lending in China. Journal of Asian Economics 18, 63-75.

Liang, Y., Tiemei, G., 2007. Empirical analysis on real estate price fluctuation in different provinces of China. Economic Research Journal 8, 133-142.

Malpezzi, S., 2012. Global perspectives on housing markets and policy, University of Wisconsin-Madison, mimeo.

McDonald, J.F., McMillen, D.P., 2011. Urban economics and real estate: Theory and policy. John Wiley \& Sons, New York.

Mian, A., Sufi, A., 2009. The consequences of mortgage credit expansion: Evidence from the US mortgage default crisis. Quarterly Journal of Economics 124, 1449-1496.

Pavlov, A., Wachter, S., 2004. Robbing the bank: Non-recourse lending and asset prices. Journal of Real Estate Finance and Economics 28, 147-160.

Pavlov, A., Wachter, S., 2007. Aggressive lending and real estate markets, University of Pennsylvania Working Paper, Vol. 566.

Pavlov, A.D., Wachter, S.M., 2006. Underpriced lending and real estate markets, SSRN Working Paper.

Peng, W., Tam, D.C., Yiu, M.S., 2008. Property market and the macroeconomy of mainland China: A cross region study. Pacific Economic Review 13, 240-258.

Peri, G., 2012. The Effect of Immigration on Productivity: Evidence from U.S. States. Review of Economics and Statistics 94, 348-358.

Ren, Y., Xiong, C., Yuan, Y., 2012. House price bubbles in China. China Economic Review 23, 786-800.

Ridker, R.G., Henning, J.A., 1967. The determinants of residential property values with special reference to air pollution. Review of Economics and Statistics 49, 246-257. 
Roback, J., 1982. Wages, rents, and the quality of life. Journal of Political Economy 90, 12571278.

Romer, P., 2014. The power of the grid. Paper presented in the 2014 World Bank Conference on Urbanization and Development.

Rosen, H.S., Rosen, K.T., 1980. Federal taxes and homeownership: Evidence from time series. Journal of Political Economy 88, 59-75.

Rosen, S., 1979. Wage-based indexes of urban quality of life, in: Mieszkowski, P., Straszheim, M. (Eds.), Current issues in urban economics, Vol. 3. Johns Hopkins University Press, Baltimore, pp. 74-104.

Schiff, N., 2012. Cities and product variety, University of British Columbia Mimeo.

Shapiro, J.M., 2006. Smart cities: Quality of life, productivity, and the growth effects of human capital. The Review of Economics and Statistics 88, 324-335.

Shen, L., 2012. Are house prices too high in China? China Economic Review 23, 1206-1210.

Sims, C.A., 2010. But economics is not an experimental science. Journal of Economic Perspectives 24, 59-68.

The Economist Magazine. 2013. When giants slow down, http://www.economist.com/news/briefing/21582257-most-dramatic-and-disruptive-periodemerging-market-growth-world-has-ever-seen.

Wang, P., Xie, D., 2011. Housing dynamics: Theory behind empirics, Washington University at St. Louis, Working Paper.

Wang, S., Yang, Z., Liu, H., 2011. Impact of urban economic openness on real estate prices: Evidence from thirty-five cities in China. China Economic Review 22, 42-54.

Wang, X., Wen, Y., 2012. Housing prices and the high Chinese saving rate puzzle. China Economic Review 23, 265-283.

Wang, Z., Zhang, Q., 2014. Fundamental factors in the housing markets of China. Journal of Housing Economics 25, 53-61. 
Wheaton, W.C., Nechayev, G., 2008. The 1998-2005 housing "bubble"and the current "correction": What's different this time? Journal of Real Estate Research 30, 1-26.

Wong, C., 2011. The fiscal stimulus programme and public governance issues in China, OECD Journal on Budgeting, 1-21.

Wu, J., Gyourko, J., Deng, Y., 2012. Evaluating conditions in major Chinese housing markets. Regional Science and Urban Economics 42, 531-543.

Zhang, T., Gong, L., Bu, Y., 2006. On the asset return, mortgage lending and property price. Journal of Financial Research 2, 1-11.

Zhao, D., Zhu, W., Wang, Z., 2008. Macroeconomic policy and publicly listed real estate firms' capital structure adjustment. Journal of Financial Research 10, 78-92.

Zheng, S., Cao, J., Kahn, M.E., 2011. China's rising demand for" green cities": Evidence from cross-city real estate price hedonics, NBER Working Paper.

Zheng, S., Fu, Y., Liu, H., 2009. Demand for urban quality of living in China: Evolution in compensating land-rent and wage-rate differentials. Journal of Real Estate Finance and Economics 38, 194-213.

Zheng, S., Kahn, M.E., 2008. Land and residential property markets in a booming economy: New evidence from Beijing. Journal of Urban Economics 63, 743-757.

Zheng, S., Kahn, M.E., Liu, H., 2010. Towards a system of open cities in China: Home prices, FDI flows and air quality in 35 major cities. Regional Science and Urban Economics 40, $1-10$. 
Figure 1 National Housing Market

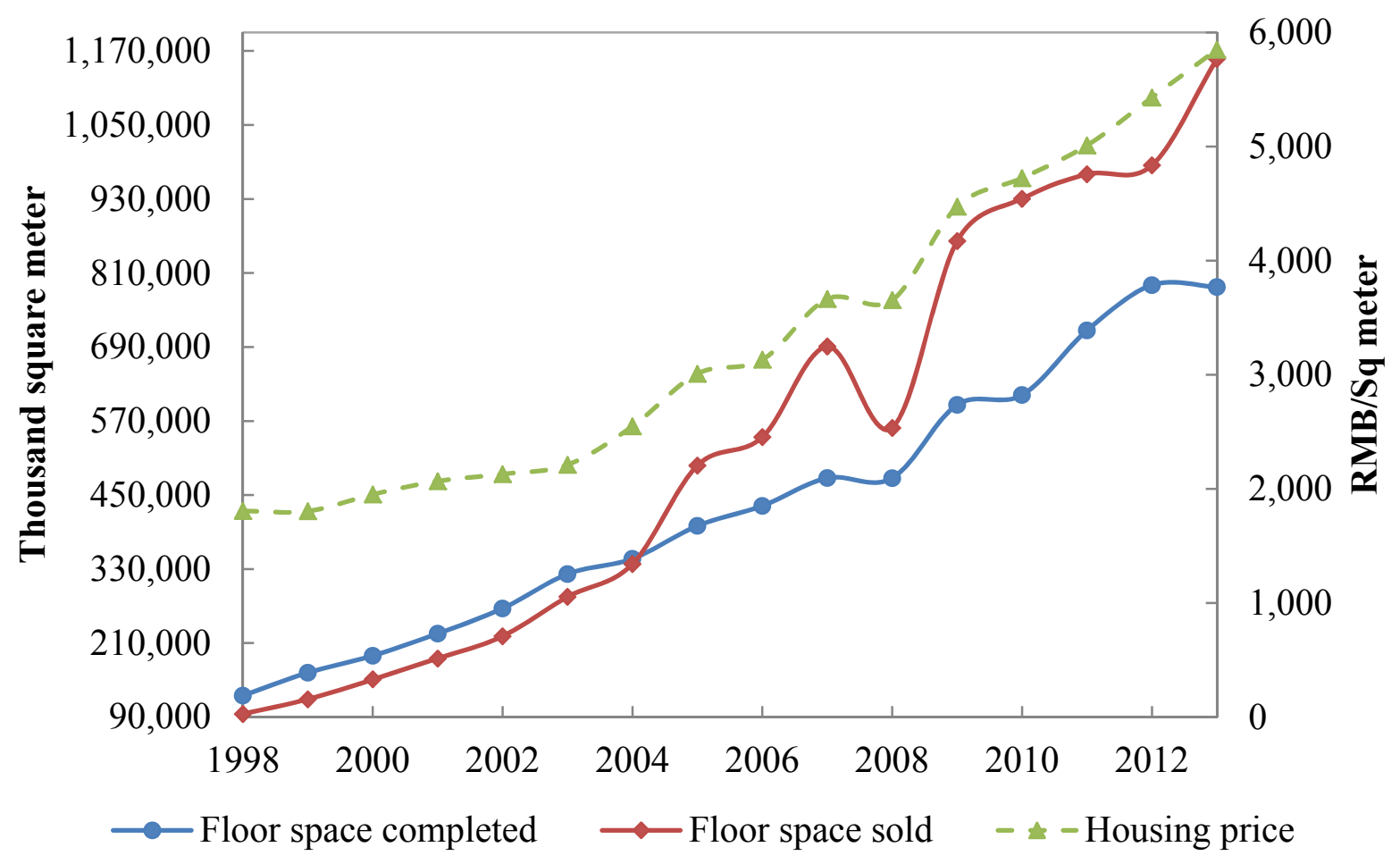

Data source: CEIC 
Figure 2 Ratio of Real Estate Investment over Total Investment

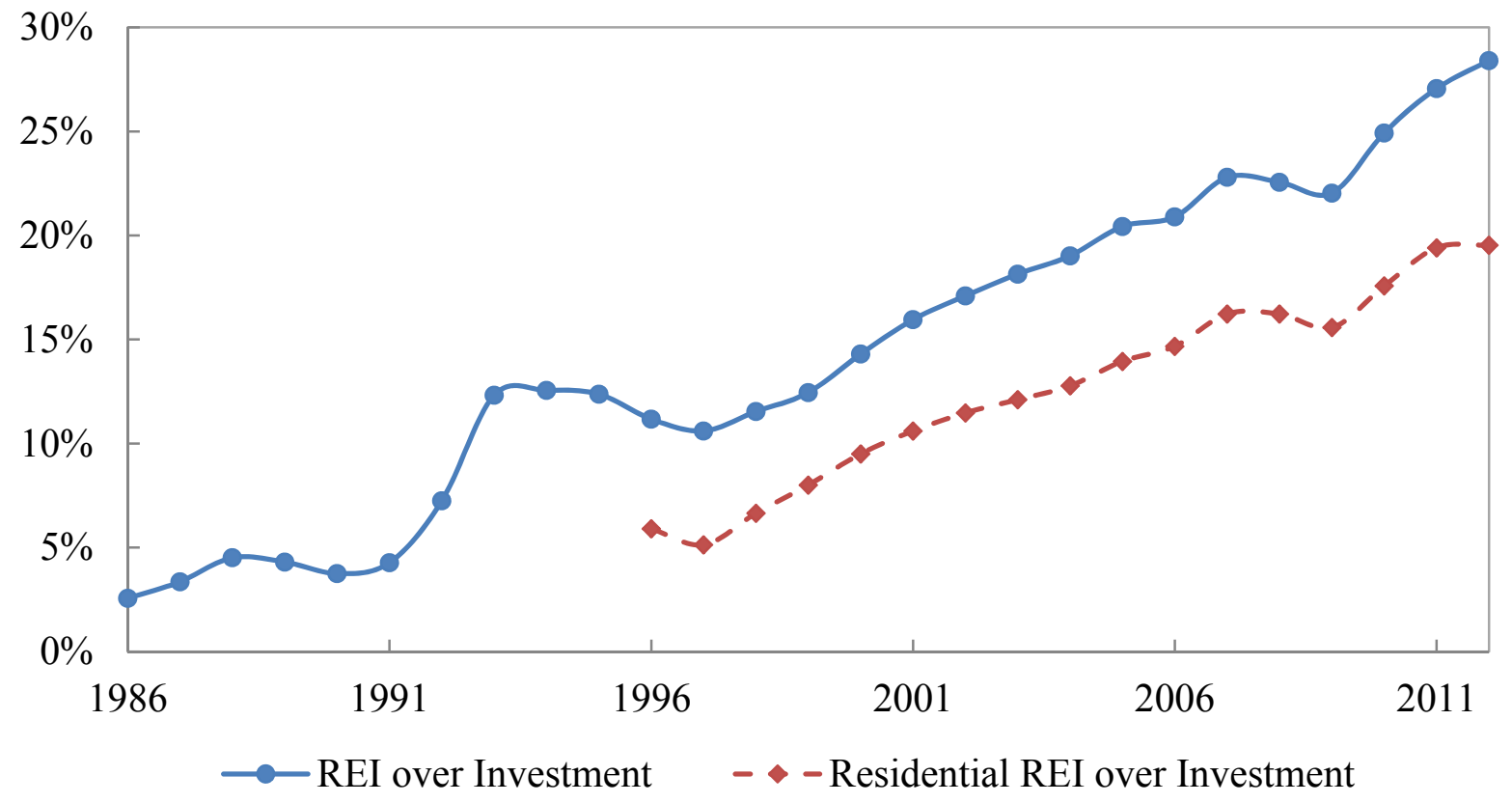

Data source: CEIC 
Figure 3 Ratios of Broad Money and Loans over GDP

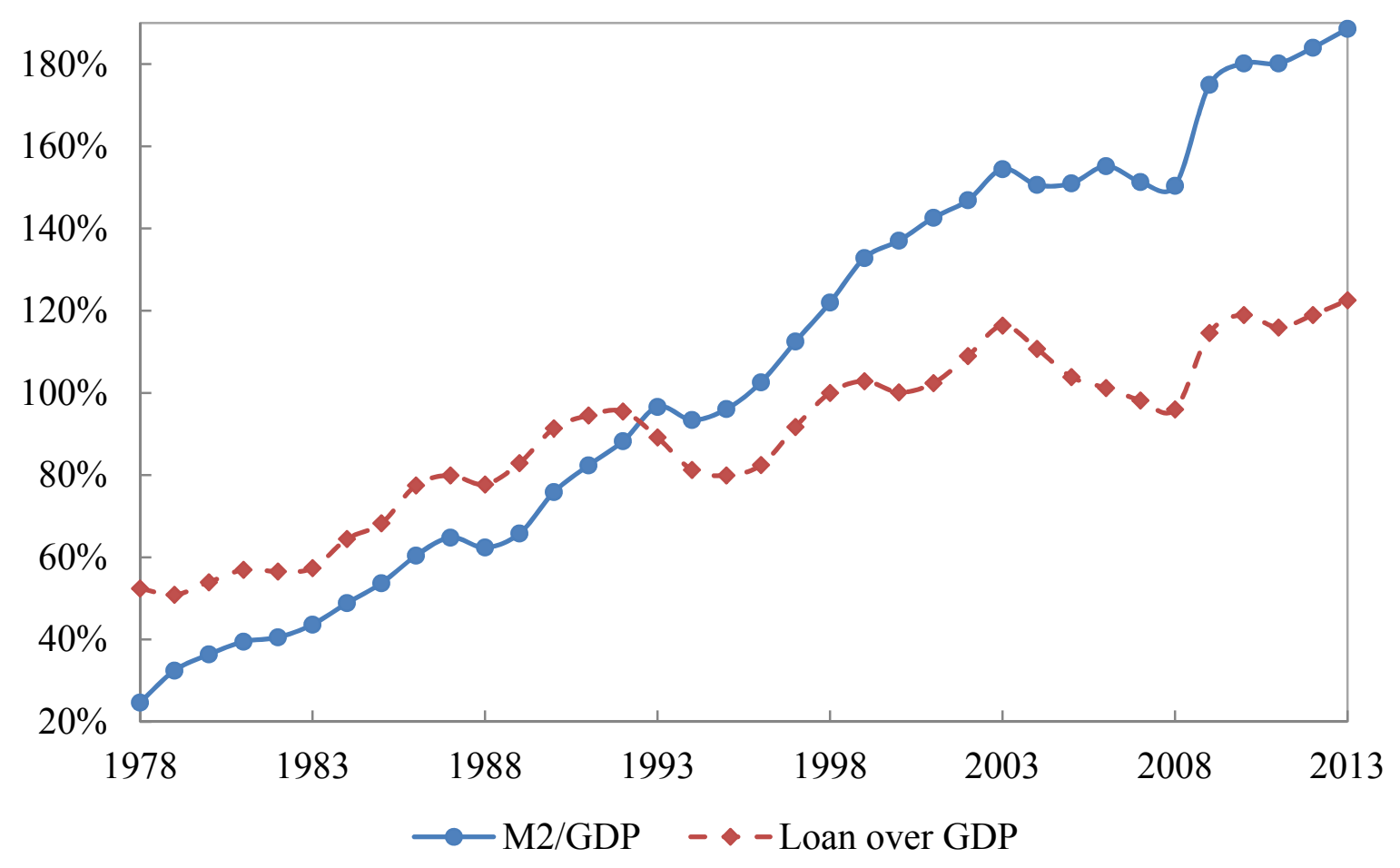

Data source: CEIC 
Figure 4 Boxplot of Chinese Cities' Hospital Sickbeds

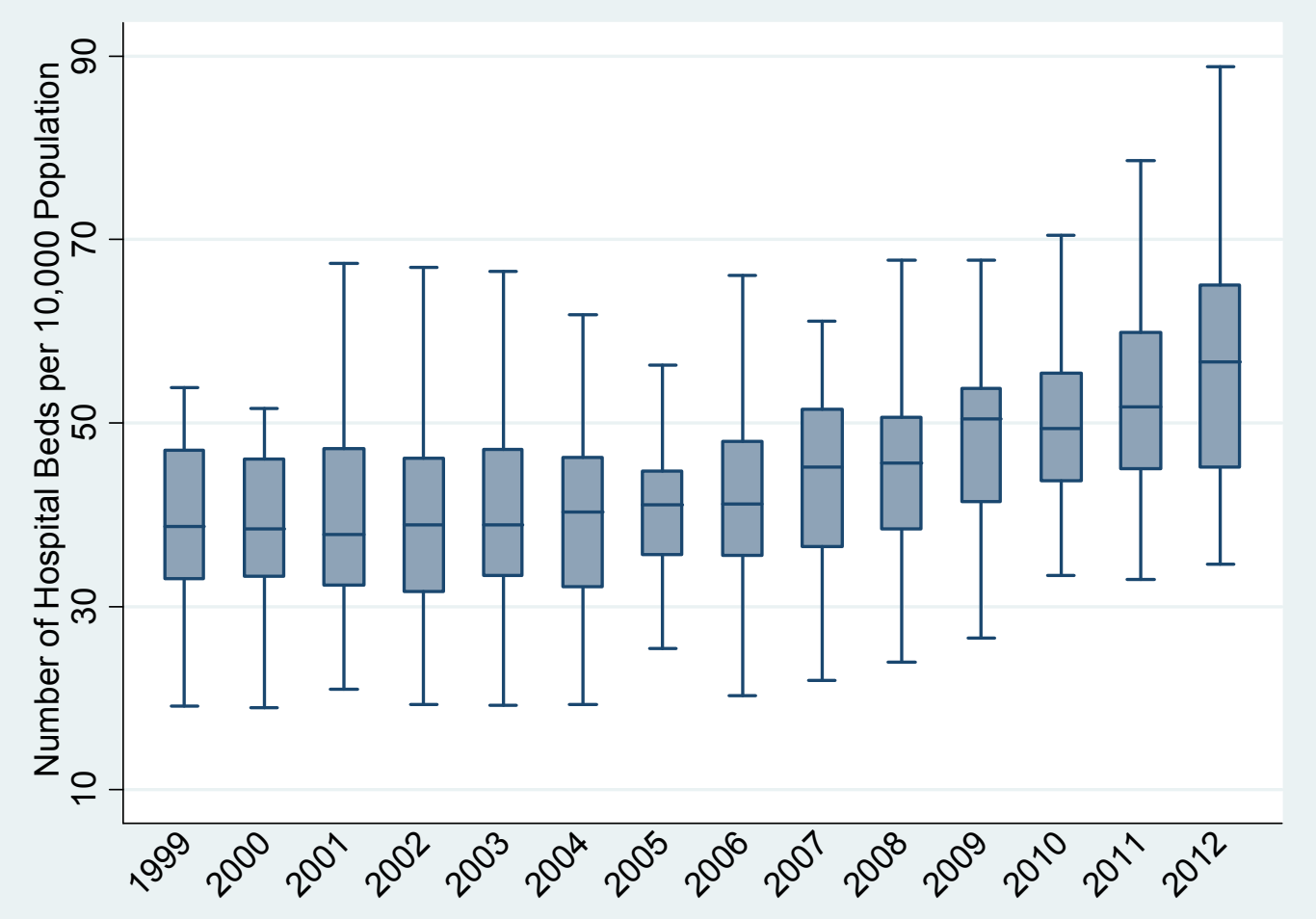

Notes: The lower hinge of each box represents the $25^{\text {th }}$ percentile, the upper hinge represents the $75^{\text {th }}$ percentile, and the line within each box indicates median. Outside values are excluded. 
Table 1 Summary Statistics

\begin{tabular}{|c|c|c|c|c|}
\hline \multirow[b]{2}{*}{ Variables } & \multicolumn{2}{|c|}{1999} & \multicolumn{2}{|c|}{2012} \\
\hline & Mean & $\begin{array}{l}\text { Standard } \\
\text { deviation }\end{array}$ & Mean & $\begin{array}{r}\text { Standard } \\
\text { deviation }\end{array}$ \\
\hline Real House Price (Yuan per Square Meter) & 2016.286 & 946.322 & 5862.114 & 2976.219 \\
\hline Real Loan (Billion Yuan) & 114.010 & 110.813 & 732.930 & 622.461 \\
\hline Loan GDP Ratio (Proportion) & 1.422 & 0.689 & 1.696 & 0.534 \\
\hline Real Income (Yuan Per Capita) & 7310.339 & 2894.575 & 21156.735 & 5717.690 \\
\hline Real Long-Term Interest $(\%)$ & 7.986 & 1.566 & 3.969 & 0.418 \\
\hline Real Stock Market Return (Proportion) & 0.192 & 0.017 & 0.024 & 0.004 \\
\hline Real Fixed Asset Investment (Billion Yuan) & 29.675 & 36.369 & 262.895 & 161.467 \\
\hline Fixed Asset Investment over GDP (Proportion) & 0.332 & 0.128 & 0.659 & 0.219 \\
\hline City-level Inflation Rate (\%) & -1.076 & 1.430 & 2.711 & 0.412 \\
\hline Maximum Temperature $\left({ }^{\circ} \mathrm{C}\right)$ & 36.181 & 2.341 & 36.291 & 2.933 \\
\hline Minimum Temperature $\left({ }^{\circ} \mathrm{C}\right)$ & -9.924 & 8.504 & -10.118 & 10.882 \\
\hline Yearly Sunshine (Hours) & 1958.747 & 570.851 & 1914.536 & 598.991 \\
\hline Yearly Precipitation (Millimeter) & 945.494 & 574.347 & 982.347 & 557.980 \\
\hline Relative Humidity (\%) & 67.294 & 10.507 & 65.933 & 11.608 \\
\hline $\mathrm{PM}_{10}$ (Micrograms per Cubic Meter) & & & 88.686 & 23.178 \\
\hline $\mathrm{SO}_{2}$ (Micrograms per Cubic Meter) & 69.818 & 56.316 & 35.171 & 14.496 \\
\hline $\mathrm{NO}_{2}$ (Micrograms per Cubic Meter) & . & . & 40.600 & 9.829 \\
\hline Days with Good Air Quality & & . & 330.824 & 24.749 \\
\hline Suspects Arrested per 10,000 Population & 5.867 & 2.008 & 7.629 & 2.976 \\
\hline Suspects Prosecuted per 10,000 Population & 6.132 & 2.357 & 11.193 & 4.212 \\
\hline Doctors per 10,000 Population & 27.884 & 10.317 & 34.354 & 16.909 \\
\hline Hospital Beds per 10,000 Population & 43.035 & 15.477 & 58.913 & 15.576 \\
\hline Population Density (Persons per Square Kilometer) & 624.338 & 477.825 & 736.278 & 641.709 \\
\hline 211 Project Universities & 3.029 & 4.662 & 3.029 & 4.662 \\
\hline Green Coverage $(\%)$ & 31.057 & 7.860 & 40.034 & 4.554 \\
\hline
\end{tabular}


Table 2 Matrix of Scoring Coefficients

\begin{tabular}{lrrrrr}
\hline Raw Measures & Comp1 & Comp2 & Comp3 & Comp4 & Comp5 \\
\hline Maximum Temperature $\left({ }^{\circ} \mathrm{C}\right)$ & 0.156 & 0.214 & 0.116 & -0.242 & 0.214 \\
Minimum Temperature $\left({ }^{\circ} \mathrm{C}\right)$ & $\mathbf{0 . 4 7 2}$ & -0.012 & -0.007 & 0.043 & 0.036 \\
Temperature Difference & $\mathbf{- 0 . 4 5 6}$ & 0.052 & 0.045 & -0.090 & -0.001 \\
Yearly Sunshine (Hours) & $\mathbf{- 0 . 4 5 5}$ & -0.081 & -0.008 & 0.124 & 0.110 \\
Yearly Precipitation (Millimeter) & 0.319 & -0.056 & 0.003 & 0.079 & 0.086 \\
Relative Humidity (\%) & $\mathbf{0 . 4 3 3}$ & -0.030 & -0.055 & -0.015 & -0.046 \\
$\mathrm{PM}_{10}$ (Micrograms per Cubic Meter) & -0.076 & $\mathbf{0 . 4 9 1}$ & -0.119 & -0.004 & 0.061 \\
$\mathrm{SO}_{2}$ (Micrograms per Cubic Meter) & 0.078 & $\mathbf{0 . 4 7 8}$ & -0.003 & 0.095 & -0.253 \\
$\mathrm{NO}_{2}$ (Micrograms per Cubic Meter) & 0.037 & 0.321 & 0.366 & 0.020 & 0.057 \\
Days with Good Air Quality & 0.025 & $\mathbf{- 0 . 5 2 8}$ & 0.083 & -0.015 & -0.078 \\
Suspects Arrested per 10,000 Population & 0.029 & -0.042 & $\mathbf{0 . 6 1 3}$ & 0.052 & -0.046 \\
Suspects Prosecuted per 10,000 Population & -0.067 & -0.072 & $\mathbf{0 . 6 3 7}$ & -0.018 & -0.020 \\
Doctors per 10,000 Population & 0.037 & -0.039 & 0.014 & $\mathbf{0 . 6 7 1}$ & 0.032 \\
Hospital Beds per 10,000 Population & -0.024 & 0.085 & 0.017 & $\mathbf{0 . 6 6 4}$ & 0.007 \\
Population Density (Persons per Square Kilometer) & 0.133 & 0.081 & 0.189 & -0.047 & $\mathbf{0 . 4 0 5}$ \\
211 Project Universities per 10,000 Population & -0.092 & 0.142 & -0.037 & 0.016 & $\mathbf{0 . 6 0 3}$ \\
Green Coverage (\%) & 0.029 & -0.217 & -0.085 & 0.065 & $\mathbf{0 . 5 6 9}$ \\
& & & & & \\
Cumulative Proportion of Variance & 0.227 & 0.393 & 0.526 & 0.637 & 0.723 \\
\hline
\end{tabular}




\section{Table 3 Empirical Model Comparison}

\begin{tabular}{cccc}
\hline & $(1)$ & $(2)$ & $(3)$ \\
& Macroeconomic Variables & Local Amenities & Both \\
\hline $\mathrm{n}$ & 223 & 223 & 223 \\
$\mathrm{k}$ & 7 & 8 & 12 \\
Adjusted R-squared & 0.80 & 0.79 & 0.85 \\
RMSE & 0.18 & 0.19 & 0.16 \\
$\mathrm{~F}$ & 28.41 & 41.12 & 69.65 \\
AIC & -116.17 & -104.27 & -166.74 \\
BIC & -88.91 & -73.61 & -122.45 \\
\hline
\end{tabular}




\section{Table 4 Housing Price Regression: Main Results}

\begin{tabular}{|c|c|c|c|c|c|c|}
\hline \multirow[b]{2}{*}{$\begin{array}{l}\text { Dependent variable: } \\
\text { log(Real House Price) }\end{array}$} & \multicolumn{2}{|c|}{ Full sample } & \multicolumn{2}{|c|}{2008 and before } & \multicolumn{2}{|c|}{ After 2008} \\
\hline & $\begin{array}{c}\text { (1) } \\
\text { Coef. }\end{array}$ & $\begin{array}{c}\text { (2) } \\
\text { Std. Coef. }\end{array}$ & $\begin{array}{l}\text { (3) } \\
\text { Coef. }\end{array}$ & $\begin{array}{c}\text { (4) } \\
\text { Std. Coef. }\end{array}$ & $\begin{array}{l}(5) \\
\text { Coef. }\end{array}$ & $\begin{array}{c}\text { (6) } \\
\text { Std. Coef. }\end{array}$ \\
\hline Lagged Loan GDP Ratio & $\begin{array}{c}0.079 \\
{[0.238]}\end{array}$ & 0.094 & $\begin{array}{c}0.081 \\
{[0.297]}\end{array}$ & 0.104 & $\begin{array}{l}0.161 * * \\
{[0.043]}\end{array}$ & 0.179 \\
\hline Filtered Income & $\begin{array}{c}1.017 * * * \\
{[0.001]}\end{array}$ & 0.324 & $\begin{array}{c}0.885 * * * \\
{[0.006]}\end{array}$ & 0.285 & $\begin{array}{c}0.965 * * * \\
{[0.006]}\end{array}$ & 0.304 \\
\hline Real Long-Term Interest & $\begin{array}{l}-0.002 \\
{[0.758]}\end{array}$ & -0.008 & $\begin{array}{c}0.009 \\
{[0.403]}\end{array}$ & 0.038 & $\begin{array}{c}0.014 \\
{[0.527]}\end{array}$ & 0.060 \\
\hline Real Stock Market Return & $\begin{array}{l}0.021 * \\
{[0.083]}\end{array}$ & 0.036 & $\begin{array}{c}0.021 \\
{[0.146]}\end{array}$ & 0.043 & $\begin{array}{l}-0.047 \\
{[0.542]}\end{array}$ & -0.057 \\
\hline Climate & $\begin{array}{c}0.010 \\
{[0.575]}\end{array}$ & 0.044 & $\begin{array}{c}0.024 \\
{[0.284]}\end{array}$ & 0.114 & $\begin{array}{c}0.016 \\
{[0.478]}\end{array}$ & 0.062 \\
\hline Air Pollution & $\begin{array}{l}-0.004 \\
{[0.734]}\end{array}$ & -0.017 & $\begin{array}{l}-0.008 \\
{[0.583]}\end{array}$ & -0.035 & $\begin{array}{c}0.040 \\
{[0.246]}\end{array}$ & 0.111 \\
\hline Crime Rate & $\begin{array}{c}0.174 * * * \\
{[0.000]}\end{array}$ & 0.677 & $\begin{array}{c}0.157 * * * \\
{[0.000]}\end{array}$ & 0.677 & $\begin{array}{c}0.183 * * * \\
{[0.000]}\end{array}$ & 0.606 \\
\hline Health Care & $\begin{array}{c}0.006 \\
{[0.744]}\end{array}$ & 0.018 & $\begin{array}{c}0.018 \\
{[0.610]}\end{array}$ & 0.049 & $\begin{array}{c}0.005 \\
{[0.806]}\end{array}$ & 0.013 \\
\hline Social Development & $\begin{array}{c}0.128 * * * \\
{[0.000]}\end{array}$ & 0.401 & $\begin{array}{c}0.122 * * * \\
{[0.000]}\end{array}$ & 0.420 & $\begin{array}{c}0.125 * * * \\
{[0.000]}\end{array}$ & 0.341 \\
\hline Constant & $\begin{array}{l}-0.034 \\
{[0.621]}\end{array}$ & & $\begin{array}{l}-0.089 \\
{[0.221]}\end{array}$ & & $\begin{array}{l}-0.079 \\
{[0.471]}\end{array}$ & \\
\hline $\begin{array}{l}\text { Observations } \\
\text { Clustered Standard Error } \\
\text { Adjusted R-squared } \\
\text { F }\end{array}$ & $\begin{array}{c}223 \\
\sqrt{ } \\
0.85 \\
69.65\end{array}$ & & $\begin{array}{c}138 \\
\sqrt{ } \\
0.83 \\
41.20\end{array}$ & & $\begin{array}{c}85 \\
\sqrt{ } \\
0.88 \\
59.95\end{array}$ & \\
\hline
\end{tabular}

Notes:

1. Clustered standard errors are computed to draw inference. $\mathrm{p}$-values are in the brackets. The stars $*, * *$, and $* * *$ indicate the significance level at $10 \%, 5 \%$, and $1 \%$ respectively.

2. House price is measured in terms of Yuan per square meter. The measurement unit of income is Yuan per capita. These two variables are first deflated, then transformed into natural logs, and finally detrended. Loan GDP ratio is detrended as well. Income is further filtered by urban amenities.

3. We subtract city-level inflation rates from nominal long-term interest rate, and nominal stock market return to obtain corresponding real values. Long-term interest rate is in percentage, while stock market return is in proportion.

4. Climate, air pollution, crime rate, health care, and social development are all principal components. Social development mainly captures population density, green space coverage, and higher education.

5. Coefficients for regional dummies are suppressed to save space. 


\section{Table 5 Loan Regression}

\begin{tabular}{|c|c|c|c|c|c|c|}
\hline \multirow[b]{2}{*}{$\begin{array}{l}\text { Dependent variable: Loan } \\
\text { GDP Ratio }\end{array}$} & \multicolumn{2}{|c|}{ Full sample } & \multicolumn{2}{|c|}{2008 and before } & \multicolumn{2}{|c|}{ After 2008} \\
\hline & $\begin{array}{l}\text { (1) } \\
\text { Coef. }\end{array}$ & $\begin{array}{c}\text { (2) } \\
\text { Std. Coef. }\end{array}$ & $\begin{array}{l}\text { (3) } \\
\text { Coef. }\end{array}$ & $\begin{array}{c}\text { (4) } \\
\text { Std. Coef. }\end{array}$ & $\begin{array}{l}\text { (5) } \\
\text { Coef. }\end{array}$ & $\begin{array}{c}\text { (6) } \\
\text { Std. Coef. }\end{array}$ \\
\hline $\begin{array}{l}\text { Lagged } \log (\text { Real House } \\
\text { Price })\end{array}$ & $\begin{array}{l}0.530 * * \\
{[0.047]}\end{array}$ & 0.414 & $\begin{array}{l}0.493 * * \\
{[0.016]}\end{array}$ & 0.371 & $\begin{array}{c}-0.054 \\
{[0.728]}\end{array}$ & -0.045 \\
\hline $\log ($ Real Income $)$ & $\begin{array}{c}-1.288^{* * *} \\
{[0.041]}\end{array}$ & -0.644 & $\begin{array}{c}-1.643^{* * * *} \\
{[0.008]}\end{array}$ & -0.843 & $\begin{array}{l}-0.723 \\
{[0.378]}\end{array}$ & -0.347 \\
\hline $\begin{array}{l}\text { Fixed Asset Investment } \\
\text { over GDP }\end{array}$ & $\begin{array}{c}0.928^{* * *} \\
{[0.000]}\end{array}$ & 0.356 & $\begin{array}{l}0.828^{* *} \\
{[0.037]}\end{array}$ & 0.217 & $\begin{array}{c}1.182 * * * \\
{[0.000]}\end{array}$ & 0.637 \\
\hline Real Long-Term Interest & $\begin{array}{l}0.023^{*} \\
{[0.079]}\end{array}$ & 0.090 & $\begin{array}{l}0.023^{*} \\
{[0.085]}\end{array}$ & 0.094 & $\begin{array}{l}-0.004 \\
{[0.712]}\end{array}$ & -0.017 \\
\hline Real Stock Market Return & $\begin{array}{c}-0.063 * * * \\
{[0.009]}\end{array}$ & -0.083 & $\begin{array}{c}-0.068 * * * \\
{[0.001]}\end{array}$ & -0.100 & $\begin{array}{c}0.009 \\
{[0.859]}\end{array}$ & 0.009 \\
\hline Constant & $\begin{array}{c}0.660 \\
{[0.109]}\end{array}$ & & $\begin{array}{c}0.910^{* * * *} \\
{[0.006]}\end{array}$ & & $\begin{array}{c}0.978^{* * *} \\
{[0.008]}\end{array}$ & \\
\hline Observations & 377 & & 261 & & 116 & \\
\hline Clustered Standard Error & $\sqrt{ }$ & & $\sqrt{ }$ & & $\sqrt{ }$ & \\
\hline Adjusted R-squared & 0.75 & & 0.77 & & 0.97 & \\
\hline
\end{tabular}

Notes:

1. Clustered standard errors are computed to draw inference. $p$-values are in the brackets. The stars $*, * *$, and $* * *$ indicate the significance level at $10 \%, 5 \%$, and $1 \%$ respectively.

2. House price is measured in terms of Yuan per square meter. The measurement unit of income is Yuan per capita. These two variables are first deflated, then transformed into natural logs, and finally detrended. Loan GDP ratio is detrended as well.

3. We subtract city-level inflation rates from nominal long-term interest rate, and nominal stock market return to obtain corresponding real values. Long-term interest rate is in percentage, while stock market return is in proportion.

4. City dummies are included but not reported to save space. 
Table 6 Housing Price Regression: Endogenous Amenities

\begin{tabular}{|c|c|c|c|c|c|c|}
\hline \multirow[b]{2}{*}{$\begin{array}{l}\text { Dependent variable: } \\
\text { log(Real House Price) }\end{array}$} & \multicolumn{2}{|c|}{ Full sample } & \multicolumn{2}{|c|}{2008 and before } & \multicolumn{2}{|c|}{ After 2008} \\
\hline & $\begin{array}{l}(1) \\
\text { Coef. }\end{array}$ & $\begin{array}{c}(2) \\
\text { Std. Coef. }\end{array}$ & $\begin{array}{l}(3) \\
\text { Coef. }\end{array}$ & $\begin{array}{c}(4) \\
\text { Std. Coef. }\end{array}$ & $\begin{array}{l}(5) \\
\text { Coef. }\end{array}$ & $\begin{array}{c}(6) \\
\text { Std. Coef. }\end{array}$ \\
\hline Lagged Loan GDP Ratio & $\begin{array}{c}0.079 \\
{[0.238]}\end{array}$ & 0.094 & $\begin{array}{c}0.081 \\
{[0.297]}\end{array}$ & 0.104 & $\begin{array}{l}0.161 * * \\
{[0.043]}\end{array}$ & 0.179 \\
\hline Filtered Income & $\begin{array}{c}3.792 * * * \\
{[0.000]}\end{array}$ & 1.207 & $\begin{array}{c}3.559 * * * \\
{[0.000]}\end{array}$ & 1.146 & $\begin{array}{c}3.799 * * * \\
{[0.000]}\end{array}$ & 1.196 \\
\hline Real Long-Term Interest & $\begin{array}{c}-0.002 \\
{[0.758]}\end{array}$ & -0.008 & $\begin{array}{c}0.009 \\
{[0.403]}\end{array}$ & 0.038 & $\begin{array}{c}0.014 \\
{[0.527]}\end{array}$ & 0.060 \\
\hline Real Stock Market Return & $\begin{array}{l}0.021^{*} \\
{[0.083]}\end{array}$ & 0.036 & $\begin{array}{c}0.021 \\
{[0.146]}\end{array}$ & 0.043 & $\begin{array}{c}-0.047 \\
{[0.542]}\end{array}$ & -0.057 \\
\hline Climate & $\begin{array}{c}0.090^{* * *} \\
{[0.000]}\end{array}$ & 0.369 & $\begin{array}{c}0.101 * * * \\
{[0.001]}\end{array}$ & 0.455 & $\begin{array}{c}0.098^{* * *} \\
{[0.000]}\end{array}$ & 0.357 \\
\hline Air Pollution & $\begin{array}{c}0.014 \\
{[0.287]}\end{array}$ & 0.055 & $\begin{array}{c}0.010 \\
{[0.523]}\end{array}$ & 0.043 & $\begin{array}{c}0.059^{*} \\
{[0.087]}\end{array}$ & 0.161 \\
\hline Crime Rate & $\begin{array}{c}0.463 * * * \\
{[0.000]}\end{array}$ & 1.260 & $\begin{array}{c}0.435 * * * \\
{[0.000]}\end{array}$ & 1.324 & $\begin{array}{c}0.478 * * * \\
{[0.000]}\end{array}$ & 1.094 \\
\hline Health Care & $\begin{array}{c}0.027 \\
{[0.177]}\end{array}$ & 0.078 & $\begin{array}{c}0.037 \\
{[0.285]}\end{array}$ & 0.106 & $\begin{array}{c}0.026 \\
{[0.190]}\end{array}$ & 0.075 \\
\hline Social Development & $\begin{array}{c}0.316^{* * *} \\
{[0.000]}\end{array}$ & 0.838 & $\begin{array}{c}0.303 * * * \\
{[0.000]}\end{array}$ & 0.901 & $\begin{array}{c}0.318^{* * *} \\
{[0.000]}\end{array}$ & 0.710 \\
\hline Constant & $\begin{array}{c}-0.034 \\
{[0.621]}\end{array}$ & & $\begin{array}{l}-0.089 \\
{[0.221]}\end{array}$ & & $\begin{array}{c}-0.079 \\
{[0.471]}\end{array}$ & \\
\hline $\begin{array}{l}\text { Observations } \\
\text { Clustered Standard Error } \\
\text { Adjusted R-squared } \\
\text { F }\end{array}$ & $\begin{array}{l}223 \\
\sqrt{ } \\
0.85 \\
69.65\end{array}$ & & $\begin{array}{c}138 \\
\sqrt{ } \\
0.83 \\
41.20\end{array}$ & & $\begin{array}{c}85 \\
\sqrt{ } \\
0.88 \\
59.95\end{array}$ & \\
\hline
\end{tabular}

Notes:

1. Clustered standard errors are computed to draw inference. p-values are in the brackets. The stars $*, * *$, and $* * *$ indicate the significance level at $10 \%, 5 \%$, and $1 \%$ respectively.

2. House price is measured in terms of Yuan per square meter. The measurement unit of income is Yuan per capita. These two variables are first deflated, then transformed into natural logs, and finally detrended. Loan GDP ratio is detrended as well. Income is further filtered by urban amenities.

3. We subtract city-level inflation rates from nominal long-term interest rate, and nominal stock market return to obtain corresponding real values. Long-term interest rate is in percentage, while stock market return is in proportion.

4. Climate, air pollution, crime rate, health care, and social development are all principal components. Social development mainly captures population density, green space coverage, and higher education.

5. Coefficients for regional dummies are suppressed to save space. 
Table 7 Housing Price Regression: Interaction Effects

\begin{tabular}{|c|c|c|c|c|c|c|}
\hline \multirow[b]{2}{*}{$\begin{array}{l}\text { Dependent variable: } \\
\text { log(Real House Price })\end{array}$} & \multicolumn{2}{|c|}{ Full sample } & \multicolumn{2}{|c|}{2008 and before } & \multicolumn{2}{|c|}{ After 2008} \\
\hline & $\begin{array}{c}(1) \\
\text { Coef. }\end{array}$ & $\begin{array}{c}(2) \\
\text { Std. Coef. }\end{array}$ & $\begin{array}{c}(3) \\
\text { Coef. }\end{array}$ & $\begin{array}{l}\text { (4) } \\
\text { Coef. }\end{array}$ & $\begin{array}{c}\text { (5) } \\
\text { Std. Coef. }\end{array}$ & $\begin{array}{l}(6) \\
\text { Coef. }\end{array}$ \\
\hline Lagged Loan GDP Ratio & $\begin{array}{c}0.125 * * \\
{[0.042]}\end{array}$ & 0.149 & $\begin{array}{c}0.044 \\
{[0.523]}\end{array}$ & 0.057 & $\begin{array}{l}0.233 * * \\
{[0.017]}\end{array}$ & 0.258 \\
\hline Filtered Income & $\begin{array}{c}3.437 * * * \\
{[0.000]}\end{array}$ & 1.094 & $\begin{array}{c}3.127 * * * \\
{[0.000]}\end{array}$ & 1.007 & $\begin{array}{c}3.408 * * * \\
{[0.000]}\end{array}$ & 1.072 \\
\hline Real Long-Term Interest & $\begin{array}{c}-0.001 \\
{[0.802]}\end{array}$ & -0.006 & $\begin{array}{c}0.009 \\
{[0.376]}\end{array}$ & 0.035 & $\begin{array}{c}-0.020 \\
{[0.333]}\end{array}$ & -0.083 \\
\hline Real Stock Market Return & $\begin{array}{c}0.016 \\
{[0.182]}\end{array}$ & 0.027 & $\begin{array}{c}0.007 \\
{[0.539]}\end{array}$ & 0.015 & $\begin{array}{c}0.085 \\
{[0.289]}\end{array}$ & 0.103 \\
\hline Climate & $\begin{array}{c}0.080 * * * \\
{[0.001]}\end{array}$ & 0.329 & $\begin{array}{c}0.082 * * * \\
{[0.003]}\end{array}$ & 0.369 & $\begin{array}{c}0.082 * * * \\
{[0.001]}\end{array}$ & 0.300 \\
\hline Air Pollution & $\begin{array}{c}0.004 \\
{[0.781]}\end{array}$ & 0.015 & $\begin{array}{c}0.012 \\
{[0.432]}\end{array}$ & 0.050 & $\begin{array}{c}0.008 \\
{[0.728]}\end{array}$ & 0.023 \\
\hline Crime Rate & $\begin{array}{c}0.435^{* * *} * \\
{[0.000]}\end{array}$ & 1.183 & $\begin{array}{c}0.421 * * * \\
{[0.000]}\end{array}$ & 1.281 & $\begin{array}{c}0.454 * * * \\
{[0.000]}\end{array}$ & 1.039 \\
\hline Health Care & $\begin{array}{c}0.028 \\
{[0.209]}\end{array}$ & 0.080 & $\begin{array}{c}0.026 \\
{[0.404]}\end{array}$ & 0.073 & $\begin{array}{c}0.049 * * * \\
{[0.008]}\end{array}$ & 0.145 \\
\hline Social Development & $\begin{array}{c}0.295 * * * \\
{[0.000]}\end{array}$ & 0.783 & $\begin{array}{c}0.276^{* * *} \\
{[0.000]}\end{array}$ & 0.820 & $\begin{array}{c}0.288 * * * \\
{[0.000]}\end{array}$ & 0.642 \\
\hline \multicolumn{7}{|l|}{ Interactive Terms } \\
\hline Climate by Loan Ratio & $\begin{array}{c}-0.082 * * \\
{[0.022]}\end{array}$ & -0.178 & $\begin{array}{c}-0.113 * * \\
{[0.010]}\end{array}$ & -0.285 & $\begin{array}{c}-0.014 \\
{[0.693]}\end{array}$ & -0.024 \\
\hline Air Pollution by Loan Ratio & $\begin{array}{c}-0.036 \\
{[0.158]}\end{array}$ & -0.088 & $\begin{array}{l}-0.023 \\
{[0.392]}\end{array}$ & -0.065 & $\begin{array}{c}0.136^{* * *} * \\
{[0.001]}\end{array}$ & 0.241 \\
\hline Crime Rate by Loan Ratio & $\begin{array}{c}-0.059^{*} \\
{[0.060]}\end{array}$ & -0.082 & $\begin{array}{c}-0.112 * * * \\
{[0.000]}\end{array}$ & -0.185 & $\begin{array}{c}-0.011 \\
{[0.856]}\end{array}$ & -0.012 \\
\hline Health Care by Loan Ratio & $\begin{array}{c}-0.089 * * * \\
{[0.001]}\end{array}$ & -0.164 & $\begin{array}{c}-0.154 * * * \\
{[0.000]}\end{array}$ & -0.241 & $\begin{array}{c}-0.018 \\
{[0.565]}\end{array}$ & -0.039 \\
\hline $\begin{array}{l}\text { Social Development by } \\
\text { Loan Ratio }\end{array}$ & $\begin{array}{r}-0.075^{*} \\
{[0.070]}\end{array}$ & -0.095 & $\begin{array}{c}-0.103 * * \\
{[0.020]}\end{array}$ & -0.162 & $\begin{array}{c}0.035 \\
{[0.645]}\end{array}$ & 0.029 \\
\hline $\begin{array}{l}\text { Observations } \\
\text { Clustered Standard Error } \\
\text { Adjusted R-squared } \\
\text { F }\end{array}$ & $\begin{array}{c}223 \\
\sqrt{ } \\
0.87 \\
115.8 \\
\end{array}$ & & $\begin{array}{c}138 \\
\sqrt{ } \\
0.86 \\
86.66\end{array}$ & & $\begin{array}{c}85 \\
\sqrt{ } \\
0.91 \\
748.4 \\
\end{array}$ & \\
\hline
\end{tabular}

Notes:

1. Clustered standard errors are computed to draw inference. p-values are in the brackets. The stars $*, * *$, and $* * *$ indicate the significance level at $10 \%, 5 \%$, and $1 \%$ respectively.

2. House price is measured in terms of Yuan per square meter. The measurement unit of income is Yuan per capita. These two variables are first deflated, then transformed into natural logs, and finally detrended. Loan GDP ratio is detrended as well. Income is further filtered by urban amenities.

3. We subtract city-level inflation rates from nominal long-term interest rate, and nominal stock market return to obtain corresponding real values. Long-term interest rate is in percentage, 
while stock market return is in proportion.

4. Climate, air pollution, crime rate, health care, and social development are all principal components, which are further filtered by income. Social development mainly captures population density, green space coverage, and higher education.

5. Constant and coefficients for regional dummies are suppressed to save space. 
Table 8 Post-recession Housing Price Panel Regression

\begin{tabular}{|c|c|c|c|c|c|c|}
\hline \multirow{3}{*}{$\begin{array}{l}\text { Dependent variable: } \\
\text { log(Real House Price) }\end{array}$} & \multicolumn{2}{|c|}{ Main Specification } & \multicolumn{2}{|c|}{ Endogenous Amenities } & \multicolumn{2}{|c|}{ Interaction Effects } \\
\hline & (1) & $(2)$ & (3) & (4) & $(5)$ & $(6)$ \\
\hline & FE & $\mathrm{RE}$ & FE & $\mathrm{RE}$ & FE & $\mathrm{RE}$ \\
\hline \multirow[t]{2}{*}{ Lagged Loan GDP Ratio } & 0.210 & $0.160 *$ & 0.210 & $0.160 *$ & $0.258 * *$ & $0.231 * * *$ \\
\hline & {$[0.111]$} & {$[0.055]$} & {$[0.111]$} & {$[0.055]$} & {$[0.018]$} & {$[0.001]$} \\
\hline \multirow[t]{2}{*}{ Filtered Income } & 0.700 & $1.261^{* * *}$ & 2.755 & $4.193 * * *$ & $4.411 * * *$ & $3.962 * * *$ \\
\hline & {$[0.276]$} & {$[0.000]$} & {$[0.117]$} & {$[0.000]$} & {$[0.010]$} & {$[0.000]$} \\
\hline \multirow[t]{2}{*}{ Real Long-Term Interest } & $-0.024^{*}$ & $-0.025 * *$ & $-0.024 *$ & $-0.025^{* *}$ & $-0.039 * *$ & $-0.035 * *$ \\
\hline & {$[0.072]$} & {$[0.025]$} & {$[0.072]$} & {$[0.025]$} & {$[0.022]$} & {$[0.011]$} \\
\hline \multirow[t]{2}{*}{ Real Stock Market Return } & 0.095 & $0.080 *$ & 0.095 & $0.080^{*}$ & $0.152 * *$ & $0.131 * * *$ \\
\hline & {$[0.110]$} & [0.056] & {$[0.110]$} & {$[0.056]$} & {$[0.018]$} & {$[0.007]$} \\
\hline \multirow[t]{2}{*}{ Climate } & -0.018 & -0.003 & 0.041 & $0.082 * * *$ & 0.101 & $0.080 * * *$ \\
\hline & {$[0.708]$} & {$[0.860]$} & {$[0.582]$} & {$[0.000]$} & {$[0.180]$} & {$[0.000]$} \\
\hline \multirow[t]{2}{*}{ Air Pollution } & 0.051 & 0.023 & 0.065 & $0.043 * *$ & 0.068 & 0.017 \\
\hline & {$[0.210]$} & {$[0.222]$} & {$[0.140]$} & {$[0.022]$} & {$[0.166]$} & {$[0.403]$} \\
\hline \multirow[t]{2}{*}{ Crime Rate } & 0.119 & $0.196^{* * *}$ & $0.333 *$ & $0.501 * * *$ & $0.509 * * *$ & $0.489 * * *$ \\
\hline & {$[0.105]$} & {$[0.000]$} & {$[0.082]$} & {$[0.000]$} & {$[0.008]$} & {$[0.000]$} \\
\hline \multirow[t]{2}{*}{ Health Care } & -0.031 & -0.016 & -0.016 & 0.006 & -0.010 & 0.022 \\
\hline & {$[0.337]$} & {$[0.371]$} & {$[0.617]$} & {$[0.750]$} & {$[0.734]$} & {$[0.236]$} \\
\hline \multirow[t]{2}{*}{ Social Development } & $0.166 * *$ & $0.143 * * *$ & $0.305 * *$ & $0.342 * * *$ & $0.427 * * *$ & $0.309 * * *$ \\
\hline & {$[0.015]$} & {$[0.000]$} & {$[0.027]$} & {$[0.000]$} & {$[0.003]$} & {$[0.000]$} \\
\hline \multicolumn{7}{|l|}{ Interactive Terms } \\
\hline \multirow[t]{2}{*}{ Climate by Loan } & & & & & $-0.080 * * *$ & -0.031 \\
\hline & & & & & {$[0.002]$} & {$[0.252]$} \\
\hline \multirow[t]{2}{*}{ Air Pollution by Loan } & & & & & 0.049 & $0.091 * *$ \\
\hline & & & & & {$[0.426]$} & {$[0.016]$} \\
\hline \multirow[t]{2}{*}{ Crime Rate by Loan } & & & & & -0.033 & -0.019 \\
\hline & & & & & {$[0.566]$} & {$[0.733]$} \\
\hline \multirow[t]{2}{*}{ Health Care by Loan } & & & & & -0.020 & -0.020 \\
\hline & & & & & {$[0.426]$} & [0.429] \\
\hline Social Development by & & & & & 0.039 & 0.049 \\
\hline Loan & & & & & {$[0.561]$} & {$[0.417]$} \\
\hline Observations & 85 & 85 & 85 & 85 & 85 & 85 \\
\hline Clustered Standard Error & $\sqrt{ }$ & $\sqrt{ }$ & $\sqrt{ }$ & $\sqrt{ }$ & $\sqrt{ }$ & $\sqrt{ }$ \\
\hline R-squared & 0.77 & & 0.77 & & 0.83 & \\
\hline Number of Cities & 29 & 29 & 29 & 29 & 29 & 29 \\
\hline $\mathrm{F}$ & 1.859 & & 1.859 & & 17.14 & \\
\hline
\end{tabular}

Notes:

1. Clustered standard errors are computed to draw inference. p-values are in the brackets. The stars $*, * *$, and $* * *$ indicate the significance level at $10 \%, 5 \%$, and $1 \%$ respectively.

2. House price is measured in terms of Yuan per square meter. The measurement unit of income is Yuan per capita. These two variables are first deflated, then transformed into natural logs, and finally detrended. Loan GDP ratio is detrended as well. Income is further filtered by urban amenities.

3. We subtract city-level inflation rates from nominal long-term interest rate, and nominal stock 
market return to obtain corresponding real values. Long-term interest rate is in percentage, while stock market return is in proportion.

4. Climate, air pollution, crime rate, health care, and social development are all principal components, which are further filtered by income. Social development mainly captures population density, green space coverage, and higher education.

5. Constant is suppressed to save space. 


\section{Appendix}

This appendix provides some supplementary materials to the main text. Appendix A is a complete list of variables used in our analysis. In appendix B, there are four housing price regressions, including one with the macroeconomic variables only, one with the PCAconsolidated amenities only, one with the 17 raw amenity measures, and one single-step regression with consolidated amenity components and unfiltered income. And several graphs in appendix $\mathrm{C}$ are to show that amenities are not constant but vary over time. 


\section{Appendix A. Variables Description and Data Sources}

\section{Table A1 Data Description}

\begin{tabular}{|c|c|c|}
\hline Variable & Description & Source \\
\hline Income & Per capita disposable income of urban household in Yuan. & CEIC \\
\hline $\begin{array}{l}\text { Long-Term } \\
\text { Interest }\end{array}$ & $\begin{array}{l}\text { Benchmark loan borrowing rate for five years or longer determined by the } \\
\text { People's Bank of China. }\end{array}$ & The People's Bank of China \\
\hline $\begin{array}{l}\text { Stock Market } \\
\text { Return }\end{array}$ & $\begin{array}{l}\text { Current-value-weighted annual aggregated market returns with cash } \\
\text { dividend reinvested. }\end{array}$ & CSMAR \\
\hline $\begin{array}{l}\text { Fixed Asset } \\
\text { Investment }\end{array}$ & $\begin{array}{l}\text { Fixed asset investment in terms of } 100 \text { million Yuan. We change the unit to } \\
\text { billion Yuan. }\end{array}$ & CEIC \\
\hline Population & $\begin{array}{l}\text { Registered population of the entire municipal district in terms of } 10,000 \\
\text { persons. Data of Beijing, Shanghai, Tianjin, and Chongqing are obtained } \\
\text { from China Statistical Yearbook for higher reliability. }\end{array}$ & $\begin{array}{l}\text { Urban Statistics Yearbook \& China } \\
\text { Statistical Yearbook }\end{array}$ \\
\hline Land Area & Land area in terms of square kilometers for the municipal districts. & Urban Statistics Yearbook \\
\hline
\end{tabular}


Table A1 Data Description (Cont'd)

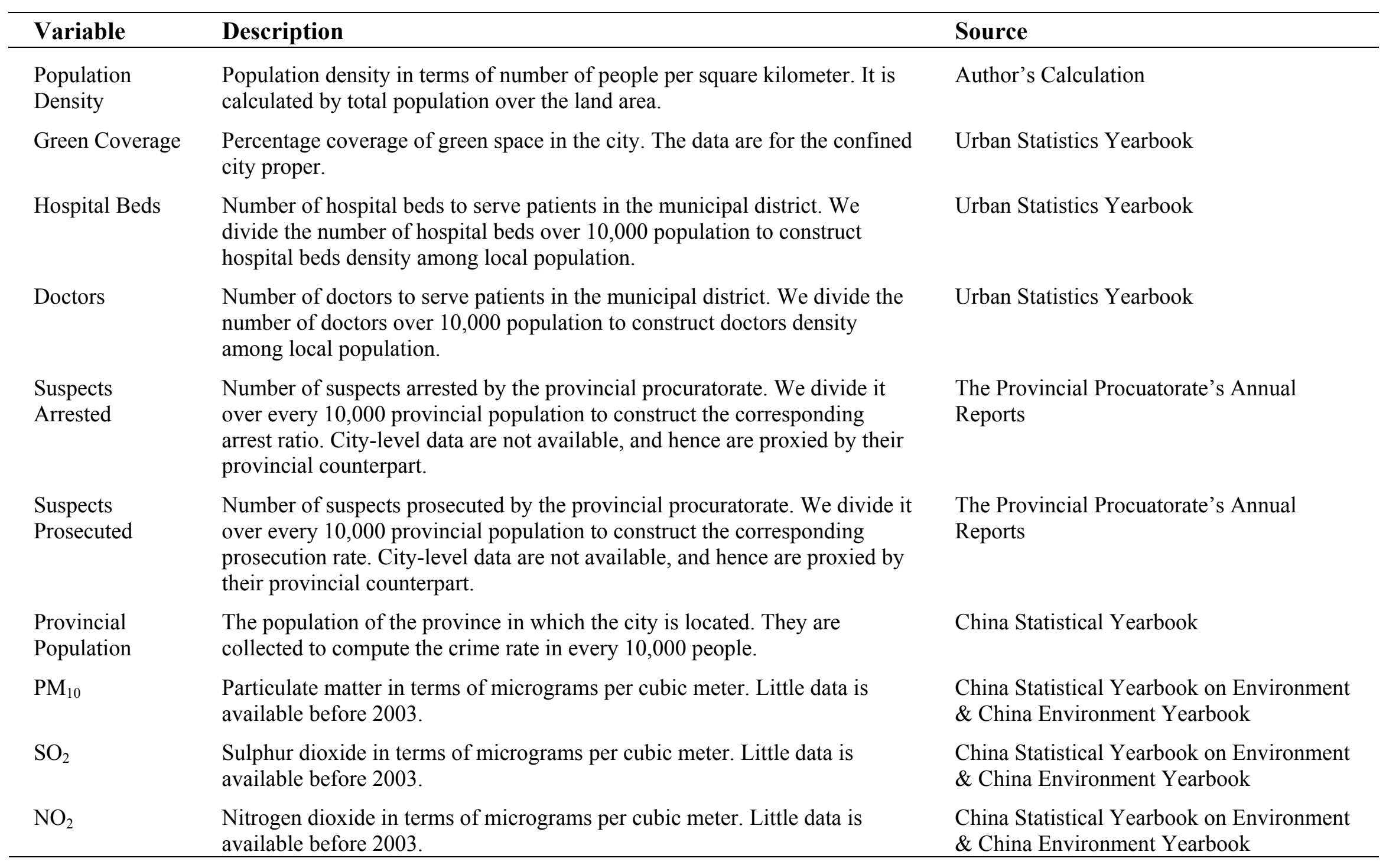




\section{Table A1 Data Description (Cont'd)}

\begin{tabular}{|c|c|c|}
\hline Variable & Description & Source \\
\hline $\begin{array}{l}\text { Maximum } \\
\text { Temperature }\end{array}$ & $\begin{array}{l}\text { The annual maximum temperature in degrees Celsius. Little data is available } \\
\text { for Ningbo. }\end{array}$ & $\begin{array}{l}\text { China Statistical Yearbook on Environment } \\
\& \text { China Meteorological Yearbook }\end{array}$ \\
\hline $\begin{array}{l}\text { Minimum } \\
\text { Temperature }\end{array}$ & $\begin{array}{l}\text { The annual maximum temperature in degrees Celsius. Little data is available } \\
\text { for Ningbo. }\end{array}$ & $\begin{array}{l}\text { China Statistical Yearbook on Environment } \\
\text { \& China Meteorological Yearbook }\end{array}$ \\
\hline $\begin{array}{l}\text { Temperature } \\
\text { Difference }\end{array}$ & It is the squared difference of annual extreme temperatures divided by 100 . & Authors' Calculation \\
\hline $\begin{array}{l}\text { Relative } \\
\text { Humidity }\end{array}$ & $\begin{array}{l}\text { The annual average humidity in percentage for } 35 \text { cities after 2003. Little } \\
\text { data is available for Dalian, Qingdao, and Xiamen. }\end{array}$ & China Statistical Yearbook on Environment \\
\hline
\end{tabular}




\section{Appendix B. Model Comparison}

This appendix provides four house price regressions, one with the macroeconomic variables only, one with the PCA-consolidated amenities only, one with the 17 raw amenity measures, and one single-step regression with consolidated amenity components and unfiltered income. All four sets of results point to equation (2) as a better empirical model.

To facilitate the model comparison in Table 3, we run a simple regression with the macroeconomic variables only and a hedonic type of regression including PCA-consolidated amenities only. To give an overview, the regression with consolidated amenities (reported in Table B2 and column (2) of Table 3) has the lowest adjusted R-squared, but the highest root mean squared error, AIC and BIC statistics. The adjusted R-squared of the regression with the macroeconomic variables (reported in Table B1 and column (1) of Table 3) is larger than the allamenities specification, but not as large as what are documented in the main text (reported in column (1) of Table 4 and column (3) of Table 3). Table B1 also has the in-between root mean squared error, AIC and BIC statistics. Clearly our empirical model combining both factors fits the sample better.

We now fill in more details about the regressions. Our discussion starts with the model controlling the macroeconomic variables only. Compared with column (1) of Table 4, estimates are greater and more significant when the amenity variables are omitted, probably because they absorb part of amenities' impacts on property prices. Recall that in Table 4, the point estimate for one-year-lagged normalized loans is 0.079 , and the standardized coefficient of the same variable is 0.094 . The point estimate increases to 0.129 , and the standardized coefficient goes up to 0.154 . The same pattern holds for the stock market return and the interest rate. Replacing filtered income with the original detrended log real income, we see quite a lift in the point estimate from 1.017 to 1.445 , and a huge raise in the standardized coefficient from 0.324 to 0.854 . Holding the macroeconomic variables constant, we find the real house price in northeast China is $14.2 \%$ higher than the price in the central part of the country.

In the following, we discuss results from the amenity regression in Table B2. Estimates

for climate and health care are larger and more significant than those in the first column of Table 4. Though staying on the same order of significance, the coefficients of social development and 
crime rate are smaller in magnitude. The estimate for air pollution changes to the wrong positive sign, but it remains insignificant. If the amenity level is held the same, home price in the east will be $25.2 \%$ higher than its counterpart in central China. The significant regional effects in this and the above table suggest there are other factors that can help explain housing prices in either Table $\mathrm{B} 1$ or B2.

As a demonstration of the multicollinearity problem, the R-squared values from regressing each amenity measure on the other 16 are summarized in Table B3. From this table, it is clear that high correlation among amenity measures is a serious issue. Eleven out of the 17 Rsquares are greater than 0.6, among which seven are around 0.9. In a housing price regression including all 17 amenities (reported in Table B4), other than the crime rates, only the variables not contaminated by multicollinearity are statistically significant. Essentially, multicollinearity means reduced amount of variations available for analysis. Together with our moderate sample size, it also works to inflate the sampling variance of the ordinary least squares estimator ${ }^{39}$. In light of this, we are not able to distinguish whether the insignificant estimates for other amenities are due to no effects indeed or whether we simply fail to find the true effects by the specification in Table B4.

Considering the compensating differentials of house prices for local amenities are partly hidden in income, we adopt a two-step strategy in Table 4. For comparison, here we provide the results of a single-step regression with amenity components and the original detrended log real income in Table B5. Coefficients on macroeconomic variables in these two tables are by and large the same. However, estimates for social development and crime rate are both quantitatively smaller and statistically less significant than those in Table 4. Estimates for climate and health care are even with the wrong signs in Table B5.

\footnotetext{
${ }^{39}$ In fact, some econometricians think multicollinearity and the problem of small sample size are just two sides of the same coin. See Goldberger (1991).
} 
Table B1 Housing Price Regression with Macroeconomic Variables

\begin{tabular}{lccc}
\hline & $(1)$ & $(2)$ & $(3)$ \\
Dependent Variable: $\log ($ Real House Price $)$ & Coef. & p-values & Std. Coef. \\
\hline & & & \\
Lagged Loan GDP Ratio & $0.129^{* *}$ & 0.023 & 0.154 \\
log(Real Income) & $1.445^{* * *}$ & 0.000 & 0.854 \\
Real Long-Term Interest & -0.005 & 0.352 & -0.022 \\
Real Stock Market Return & $0.033^{* *}$ & 0.016 & 0.057 \\
Eastern Dummy & 0.050 & 0.704 & 0.060 \\
Northeastern Dummy & $0.142^{*}$ & 0.084 & 0.115 \\
Western Dummy & 0.002 & 0.978 & 0.002 \\
Constant & -0.027 & 0.721 & \\
& & & \\
Observations & 223 & & \\
Clustered Standard Error & $\sqrt{ }$ & & \\
Adjusted R-squared & 0.80 & & \\
F & 28.41 & & \\
\hline
\end{tabular}

Notes:

1. To facilitate the comparison of empirical models, we restrict the sample to the same one as in Table 4.

2. Clustered standard errors are computed to draw inference. The stars *, **, and $* * *$ indicate the significance level at $10 \%, 5 \%$, and $1 \%$ respectively.

3. House price is measured in terms of Yuan per square meter. The measurement unit of income is Yuan per capita. These two variables are first deflated, then transformed into natural logs, and finally detrended. Loan GDP ratio is detrended as well.

4. We subtract city-level inflation rates from nominal long-term interest rate, and nominal stock market return to obtain corresponding real values. Longterm interest rate is in percentage, while stock market return is in proportion. 


\section{Table B2 Housing Price Regression with Local Amenities}

\begin{tabular}{lccc}
\hline & $(1)$ & $(2)$ & $(3)$ \\
Dependent Variable: $\log ($ Real House Price) & Coef. & p-values & Std. Coef. \\
\hline Climate & & & \\
Air Pollution & 0.030 & 0.206 & 0.130 \\
Crime Rate & 0.004 & 0.775 & 0.016 \\
Health Care & $0.113^{* * *}$ & 0.000 & 0.439 \\
Social Development & 0.045 & 0.121 & 0.129 \\
Eastern Dummy & $0.112^{* * *}$ & 0.000 & 0.350 \\
Northeastern Dummy & $0.252^{* *}$ & 0.027 & 0.299 \\
Western Dummy & 0.110 & 0.331 & 0.089 \\
Constant & -0.085 & 0.335 & -0.091 \\
& -0.108 & 0.131 & \\
Observations & & & \\
Clustered Standard Error & 223 & & \\
Adjusted R-squared & $\sqrt{ }$ & & \\
F & 0.79 & & \\
\hline
\end{tabular}

Notes:

1. Clustered standard errors are computed to draw inference. The stars *,**, and $* * *$ indicate the significance level at $10 \%, 5 \%$, and $1 \%$ respectively.

2. House price is measured in terms of Yuan per square meter. The variable is first deflated, then transformed into natural logs, and finally detrended.

3. Climate, air pollution, crime rate, health care, and social development are all principal components. Social development mainly captures population density, green space coverage, and higher education. 
Table B3 Multicollinearity among Amenity Measures

\begin{tabular}{lc}
\hline Independent Variables & R-squared \\
\hline Maximum Temperature $\left({ }^{\circ} \mathrm{C}\right)$ & $\mathbf{0 . 9 2}$ \\
Minimum Temperature $\left({ }^{\circ} \mathrm{C}\right)$ & $\mathbf{0 . 9 9}$ \\
Temperature Difference & $\mathbf{0 . 9 9}$ \\
Yearly Sunshine (100 Hours) & $\mathbf{0 . 7 4}$ \\
Yearly Precipitation (100 Millimeter) & 0.38 \\
Relative Humidity (\%) & $\mathbf{0 . 7 5}$ \\
$\mathrm{PM}_{10}$ (100 Micrograms per Cubic Meter) & $\mathbf{0 . 8 9}$ \\
$\mathrm{SO}_{2}$ (Micrograms per Cubic Meter) & 0.41 \\
$\mathrm{NO}_{2}$ (Micrograms per Cubic Meter) & 0.34 \\
Days with Good Air Quality & $\mathbf{0 . 8 8}$ \\
Suspects Arrested per 10,000 Population & $\mathbf{0 . 8 9}$ \\
Suspects Prosecuted per 10,000 Population & $\mathbf{0 . 8 8}$ \\
Doctors per 10,000 Population & $\mathbf{0 . 6 8}$ \\
Hospital Beds per 10,000 Population & $\mathbf{0 . 6 3}$ \\
log(Population Density) & 0.49 \\
211 Project Universities per 10,000 Population & 0.28 \\
Green Coverage (\%) & 0.32 \\
\hline
\end{tabular}

Notes: R-squared in the first row is obtained from the regression of maximum temperature on all the other variables in this table. Other $\mathrm{R}$-squared values are obtained in the same way, where the variable explicitly listed in the row plays the role of a dependent variable, and all the other variables in the table are independent variables. 
Table B4 Housing Price Regression with Raw Amenity Measures

\begin{tabular}{|c|c|c|c|}
\hline Dependent Variable: $\log ($ Real House Price $)$ & $\begin{array}{c}(1) \\
\text { Coef. }\end{array}$ & $\begin{array}{c}(2) \\
\text { p-values }\end{array}$ & $\begin{array}{c}\text { (3) } \\
\text { Std. Coef. }\end{array}$ \\
\hline Lagged Loan GDP Ratio & 0.068 & 0.383 & 0.081 \\
\hline Filtered Income & $0.892 * * *$ & 0.004 & 0.261 \\
\hline Real Long-Term Interest & -0.003 & 0.674 & -0.011 \\
\hline Real Stock Market Return & $0.025^{*}$ & 0.083 & 0.043 \\
\hline Maximum Temperature $\left({ }^{\circ} \mathrm{C}\right)$ & 0.006 & 0.789 & 0.044 \\
\hline Minimum Temperature $\left({ }^{\circ} \mathrm{C}\right)$ & -0.000 & 0.986 & -0.010 \\
\hline Temperature Difference & 0.002 & 0.924 & 0.048 \\
\hline Yearly Sunshine (100 Hours) & 0.004 & 0.565 & 0.046 \\
\hline Yearly Precipitation (100 Millimeter) & $0.004 * *$ & 0.042 & 0.062 \\
\hline Relative Humidity $(\%)$ & -0.002 & 0.496 & -0.046 \\
\hline $\mathrm{PM}_{10}$ (100 Micrograms per Cubic Meter) & -0.050 & 0.783 & -0.030 \\
\hline $\mathrm{SO}_{2}$ (Micrograms per Cubic Meter) & $-0.004 * * *$ & 0.001 & -0.187 \\
\hline $\mathrm{NO}_{2}$ (Micrograms per Cubic Meter) & $0.005 * *$ & 0.012 & 0.156 \\
\hline Days with Good Air Quality & -0.001 & 0.322 & -0.092 \\
\hline Suspects Arrested per 10,000 Population & $0.047 * *$ & 0.016 & 0.334 \\
\hline Suspects Prosecuted per 10,000 Population & $0.024 *$ & 0.069 & 0.225 \\
\hline Doctors per 10,000 Population & 0.006 & 0.323 & 0.127 \\
\hline Hospital Beds per 10,000 Population & -0.003 & 0.380 & -0.092 \\
\hline $\log ($ Population Density) & $0.266^{* * *}$ & 0.000 & 0.410 \\
\hline 211 Project Universities per 10,000 Population & 3.575 & 0.581 & 0.033 \\
\hline Green Coverage $(\%)$ & 0.004 & 0.184 & 0.062 \\
\hline Observations & 223 & & \\
\hline Clustered Standard Error & $\sqrt{ }$ & & \\
\hline Adjusted R-squared & 0.86 & & \\
\hline $\mathrm{F}$ & 169.9 & & \\
\hline
\end{tabular}

Notes:

1. Clustered standard errors are computed to draw inference. The stars *,**, and $* * *$ indicate the significance level at $10 \%, 5 \%$, and $1 \%$ respectively.

2. House price is measured in terms of Yuan per square meter. The measurement unit of income is Yuan per capita. These two variables are first deflated, then transformed into natural logs, and finally detrended. Income is further filtered by the raw amenity measures. Loan GDP ratio is detrended as well.

3. We subtract city-level inflation rates from nominal long-term interest rate, and nominal stock market return to obtain corresponding real values. Long-term interest rate is in percentage, while stock market return is in proportion.

4. Constant and coefficients for regional dummies are suppressed to save space. 
Table B5 Housing Price Regression in One Step

\begin{tabular}{lccc}
\hline & $(1)$ & $(2)$ & $(3)$ \\
Dependent Variable: $\log ($ Real House Price $)$ & Coef. & p-values & Std. Coef. \\
\hline & & & \\
Lagged Loan GDP Ratio & 0.079 & 0.238 & 0.094 \\
log(Real Income) & $1.017^{* * *}$ & 0.001 & 0.601 \\
Real Long-Term Interest & -0.002 & 0.758 & -0.008 \\
Real Stock Market Return & $0.021^{*}$ & 0.083 & 0.036 \\
Climate & -0.019 & 0.356 & -0.082 \\
Air Pollution & -0.011 & 0.392 & -0.043 \\
Crime Rate & $0.068^{* * *}$ & 0.003 & 0.265 \\
Health Care & -0.001 & 0.948 & -0.004 \\
Social Development & $0.059^{* * *}$ & 0.003 & 0.184 \\
Eastern Dummy & 0.009 & 0.944 & 0.010 \\
Northeastern Dummy & 0.019 & 0.855 & 0.015 \\
Western Dummy & -0.002 & 0.980 & -0.002 \\
Constant & -0.009 & 0.901 & \\
& & & \\
Observations & 223 & & \\
Clustered Standard Error & $\sqrt{ }$ & & \\
R-squared & 0.85 & & \\
F & 69.65 & & \\
\hline
\end{tabular}

Notes:

1. Clustered standard errors are computed to draw inference. The stars *, **, and $* * *$ indicate the significance level at $10 \%, 5 \%$, and $1 \%$ respectively.

2. House price is measured in terms of Yuan per square meter. The measurement unit of income is Yuan per capita. These two variables are first deflated, then transformed into natural logs, and finally detrended. Loan GDP ratio is detrended as well.

3. We subtract city-level inflation rates from nominal long-term interest rate, and nominal stock market return to obtain corresponding real values. Longterm interest rate is in percentage, while stock market return is in proportion.

4. Climate, air pollution, crime rate, health care, and social development are all principal components. Social development mainly captures population density, green space coverage, and higher education. 


\section{Appendix C. Changing Amenities}

In this appendix, we provide several graphs to show that amenities are not constant but vary over time. Figure $\mathrm{C} 1$ to $\mathrm{C} 5$ are the box plots for the amenity components. It is clear from these plots that crime rate, healthcare condition, and social development indicator have been increasing. Air quality generally has been improved. And there is no pattern in climate. Figure $\mathrm{C} 6$ to $\mathrm{C} 8$ include three marked evolving paths of certain amenities in individual cities as specific examples. 
Figure C1 Boxplot of Climate

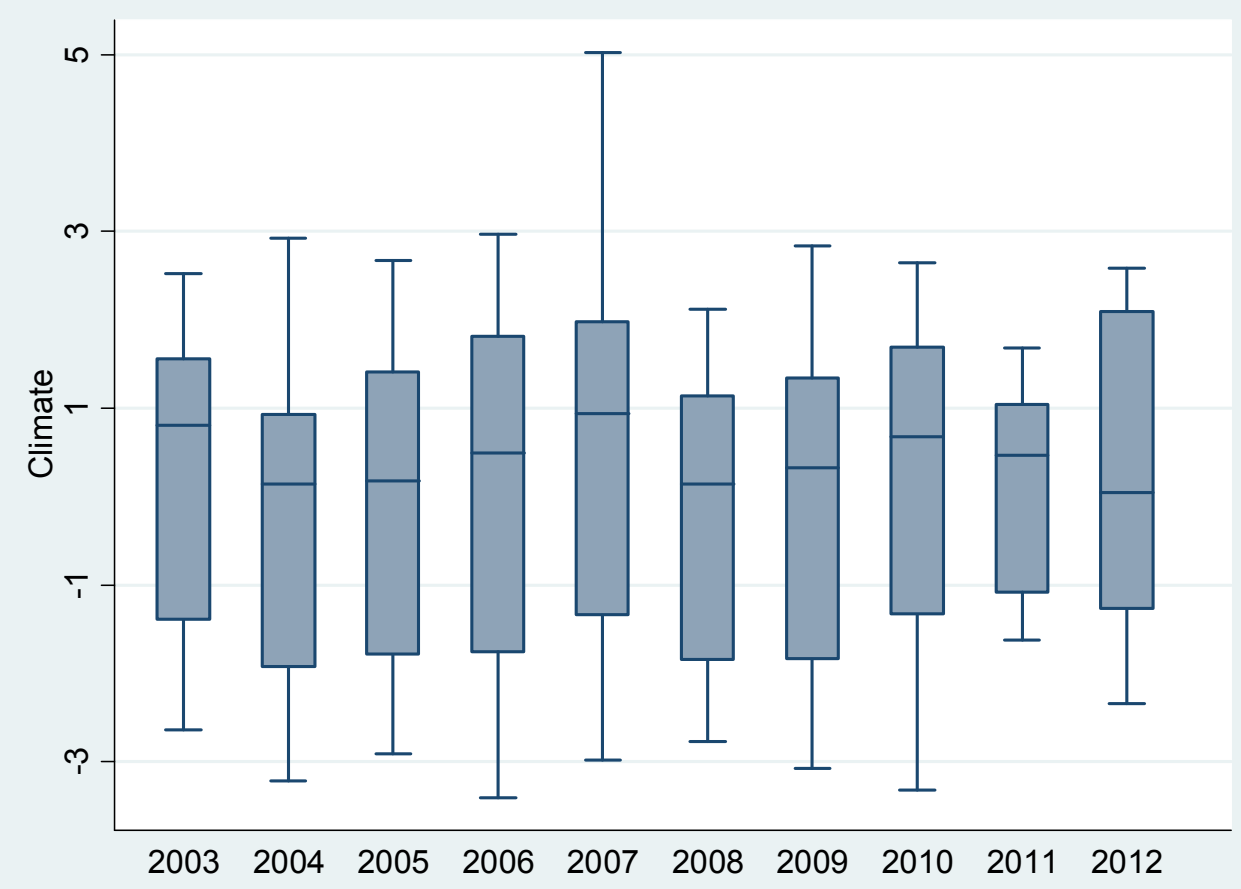

Figure C2 Boxplot of Air Pollution

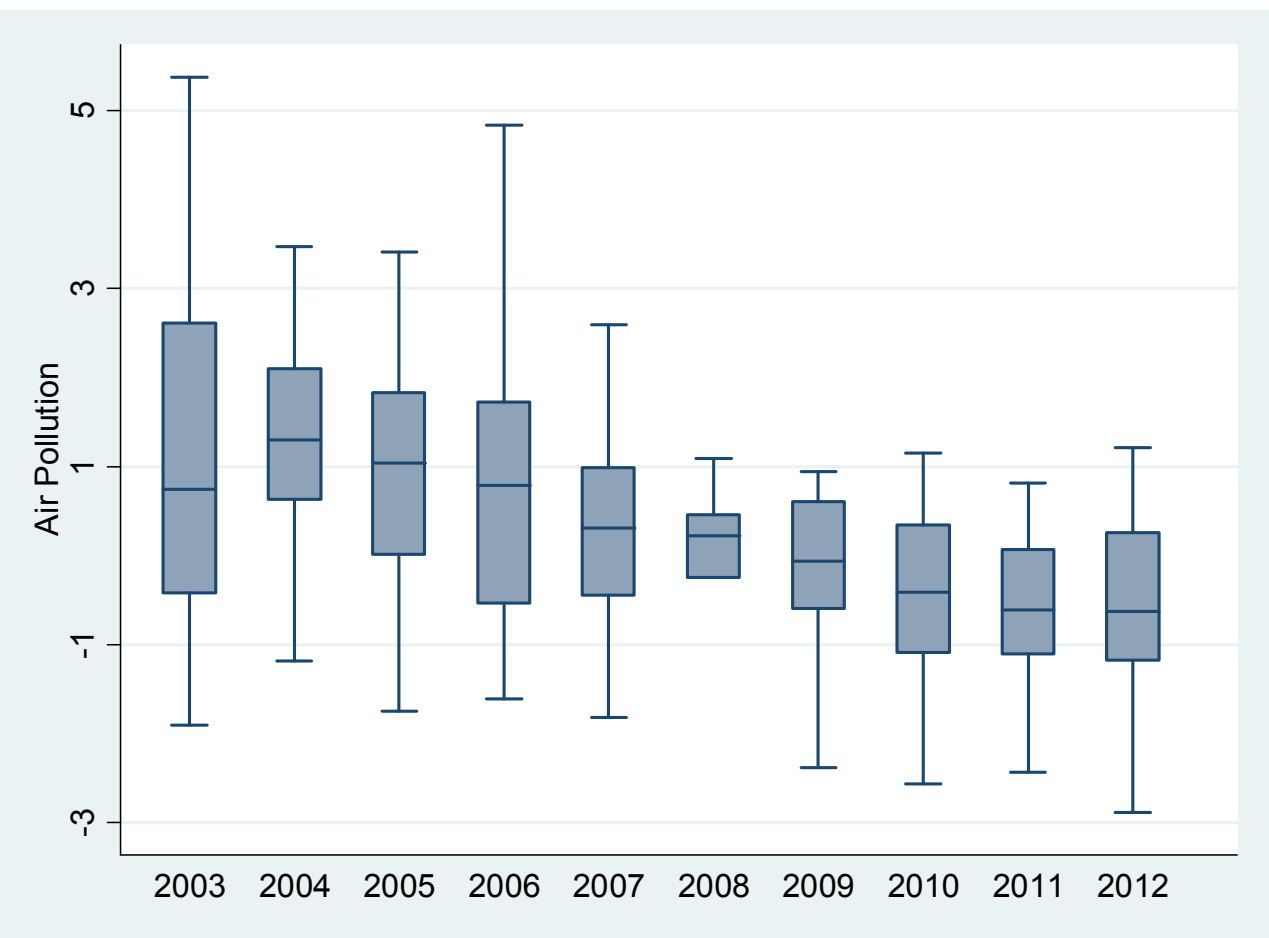


Figure C3 Boxplot of Crime Rate

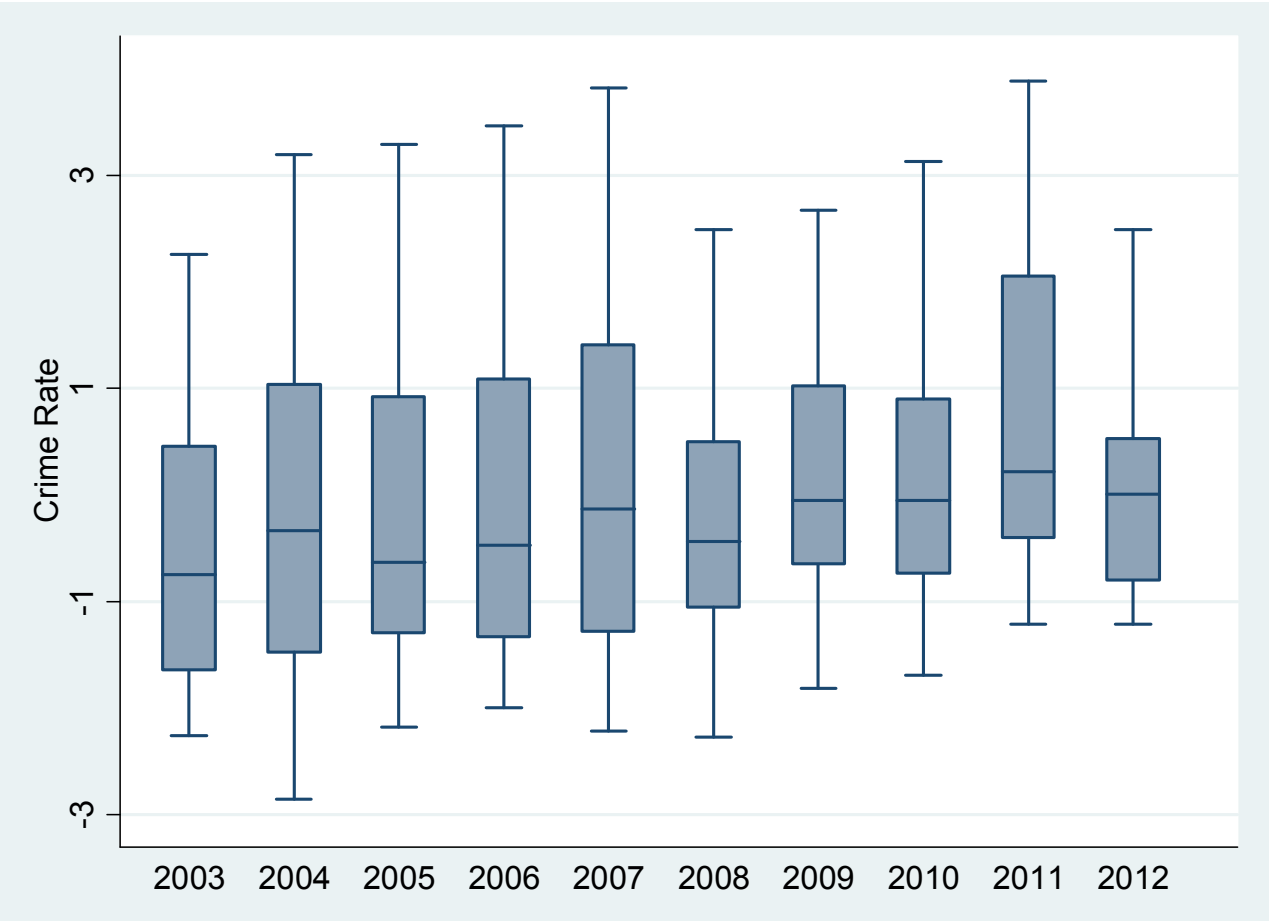

Figure C4 Boxplot of Health Care

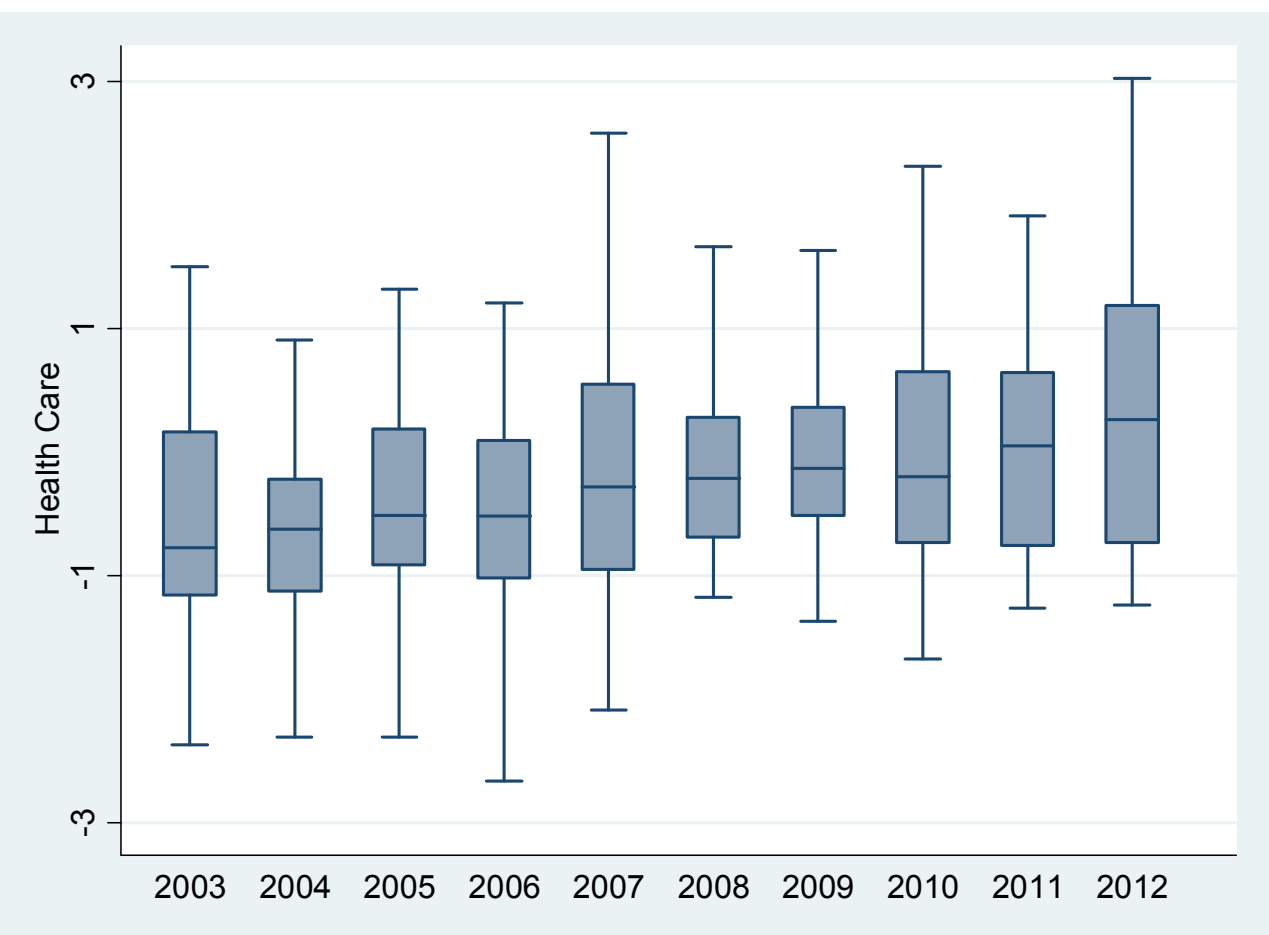


Figure C5 Boxplot of Social Development

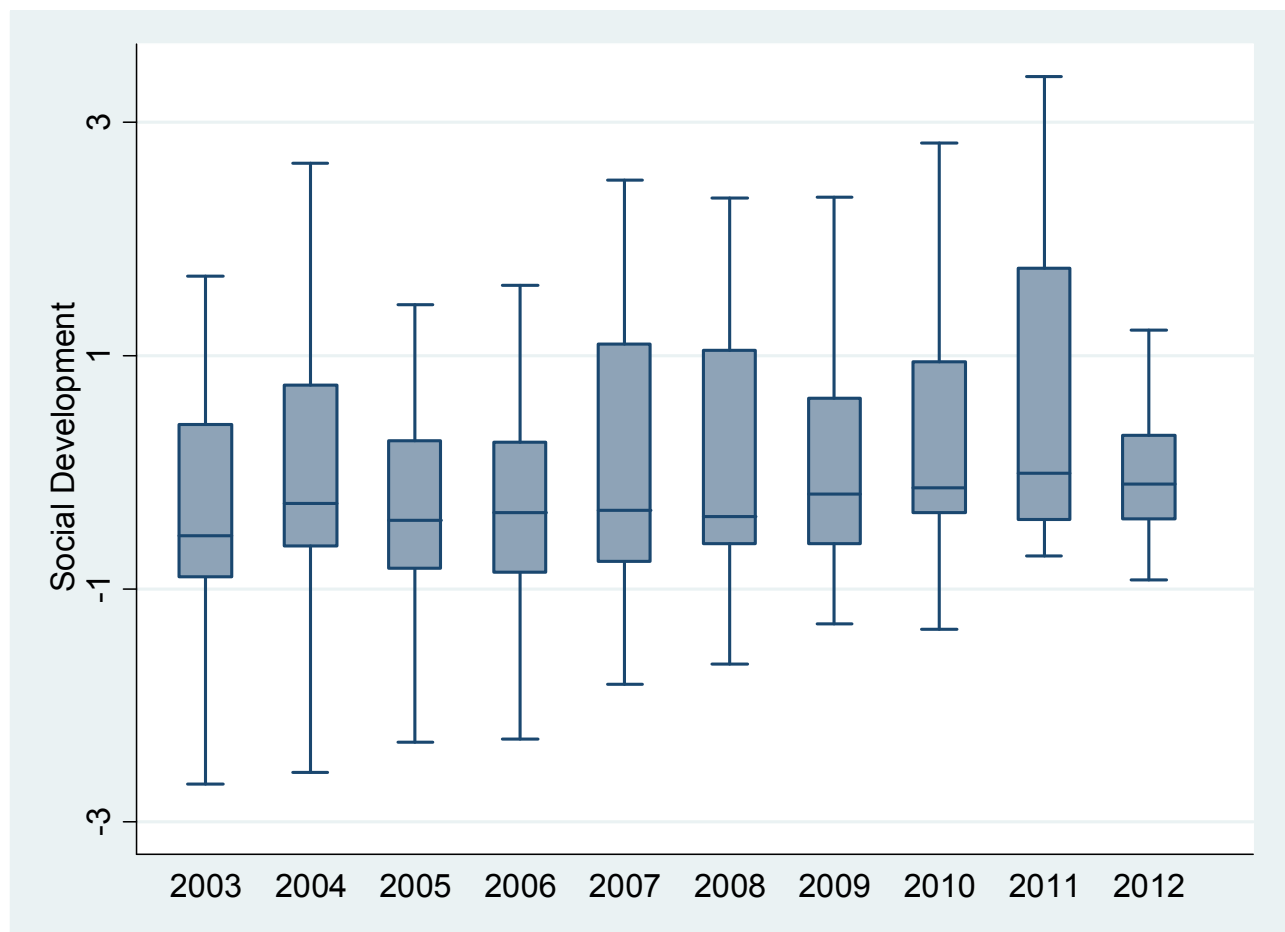

Notes:

1. The vertical axis stands for the corresponding principal component.

2. The lower hinge of each box represents the $25^{\text {th }}$ percentile, the upper hinge represents the $75^{\text {th }}$ percentile, and the line within each box indicates median. 
Figure C6 Population Density in Beijing

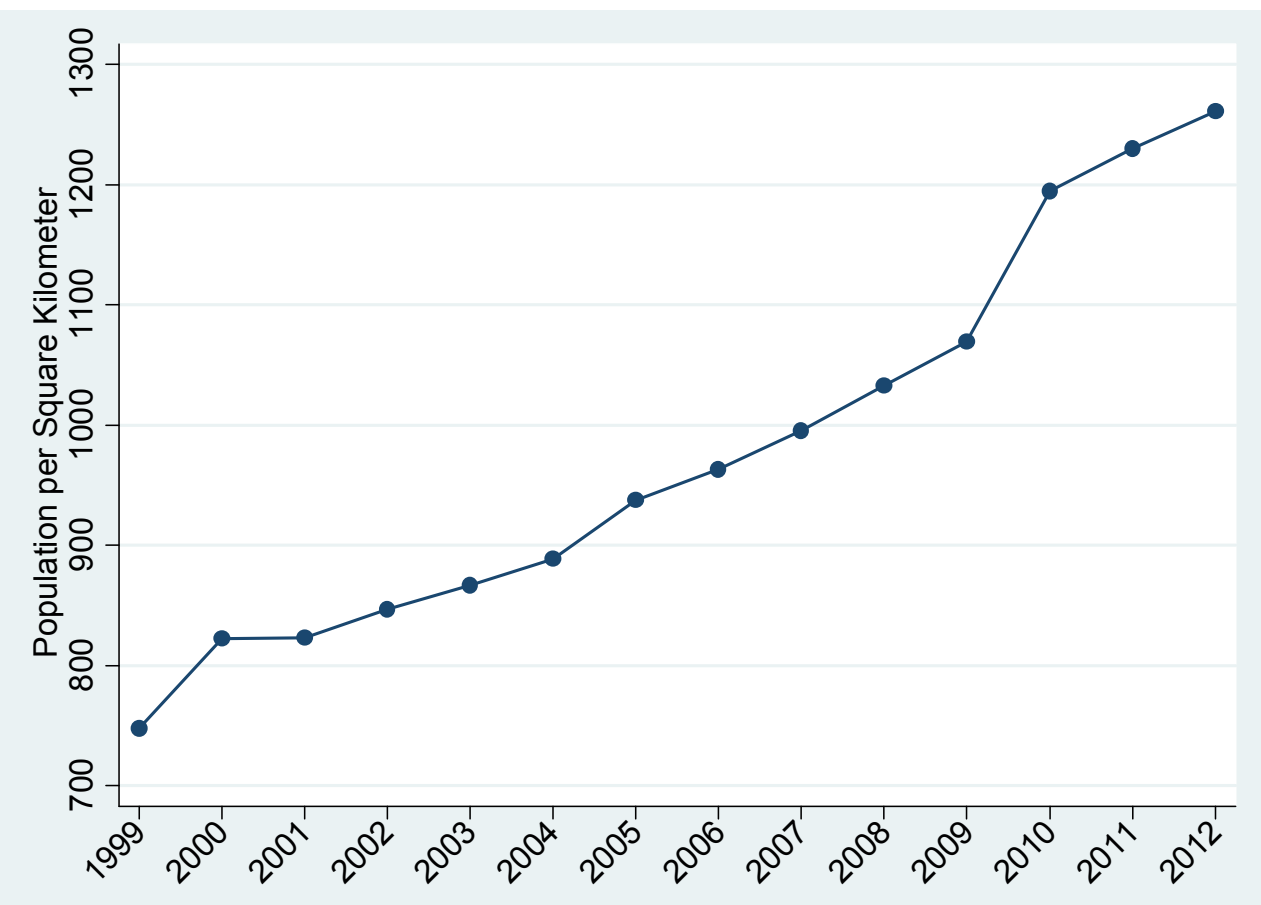

Figure C7 Number of Hospital Beds in Chengdu

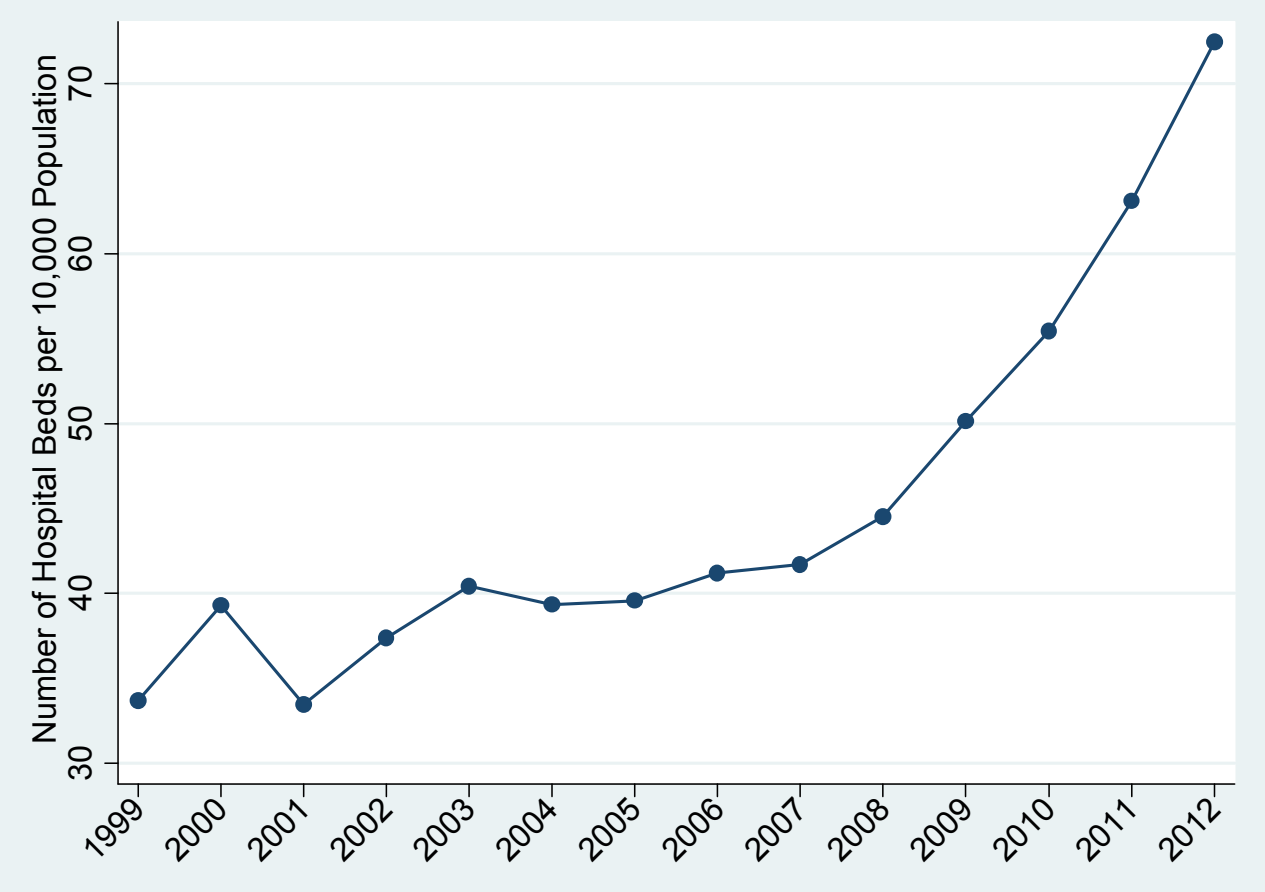


Figure C8 Green Coverage in Chongqing

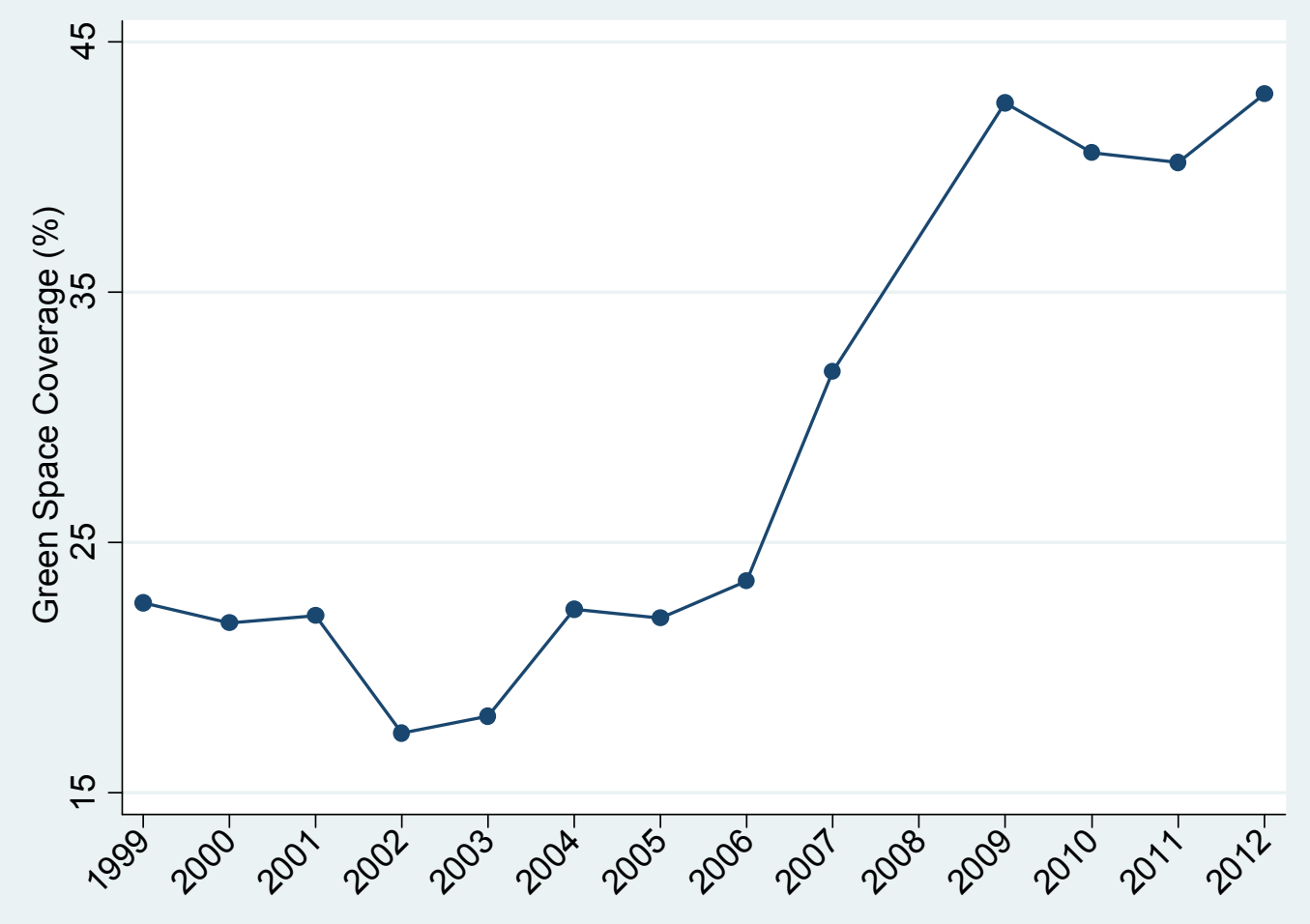

